\title{
Factors Influencing Brown Trout Reproductive Success in Ozark Tailwater Rivers
}

\author{
Danielle R. Pender ${ }^{1}$ And Thomas J. KwaK*2 \\ Arkansas Cooperative Fish and Wildlife Research Unit, ${ }^{3}$ U.S. Geological Survey, \\ Department of Biological Sciences, University of Arkansas, \\ Fayetteville, Arkansas 72701, USA
}

\begin{abstract}
The reproductive success of brown trout Salmo trutta in White River, Arkansas, tailwater reaches is highly variable, resulting in the need for supplemental stocking. A better understanding of the physical and biotic factors affecting reproduction and survival would enhance the contribution of wild fish. We compared fecundity, reproductive chronology, physical habitat, water quality, trout density, food availability, diet, predation, and competitive interactions among four tailwater reaches to identify factors influencing brown trout reproductive success. The fecundity and condition factor of prespawning brown trout were significantly lower at Beaver Tailwater, a reach known for reproductive failure, than at other sites, among which no differences were found. Brown trout spawning was observed from 11 October to 23 November 1996, and juvenile emergence began on 28 February 1997. Significant among-site differences were detected for spawning and juvenile microhabitat variables, but the variables fell within or near suitable or optimal ranges reported in the literature for this species. Age-0 brown trout density differed significantly among sites, but growth and condition did not. Predation by Ozark sculpin Cottus hypselurus on trout eggs or age-0 trout of any species was not observed among the 418 stomachs examined. Ozark sculpin density and diet overlap with age- 0 brown trout were highest and invertebrate food availability and water fertility were lowest at Beaver Tailwater relative to the other reaches. Our findings indicate that differences in trophic conditions occur among tailwater reaches, and a lower system productive capacity was identified at Beaver Tailwater. We suggest that management efforts include refining the multispecies trout stocking regime to improve production efficiency, enhancing flow regulation, and increasing habitat complexity to increase invertebrate and fish productivity. Such efforts may lead to improved natural reproduction and the increased abundance and quality of wild trout in this system and other regulated rivers.
\end{abstract}

Reproductive ecology is a critical aspect of trout life history. Trout require specific spawning, incubation, and rearing habitats to maintain wild populations. At some point within the early life history of brown trout Salmo trutta, a bottleneck or critical period typically occurs that results in survival to the yearling stage as low as 3\% (Mills 1971; Elliott 1993a, 1994). This low early survival may be attributed to some combination of the following physical and biotic factors: adult female fecundity, age- 0 trout density, food availability, predation, interspecific competition, and spawn-

\footnotetext{
* Corresponding author: tkwak@ncsu.edu

${ }^{1}$ Present address: North Carolina Wildlife Resources Commission, Habitat Conservation Program, 1142 I-85 Service Road, Creedmoor, North Carolina 27522, USA.

2 Present address: North Carolina Cooperative Fish and Wildlife Research Unit, U.S. Geological Survey, Box 7617, North Carolina State University, Raleigh, North Carolina 27695, USA.

3 The Unit is jointly supported by the Arkansas Game and Fish Commission, University of Arkansas, U.S. Geological Survey, and Wildlife Management Institute.
}

Received November 9, 2000; accepted January 14, 2002 ing, incubation, and rearing habitat characteristics. McNeil and Ahnell (1964) reported that a critical period in the life history of salmonids occurs between egg deposition and age-0 salmonid emergence. Conversely, survival during this period also may be quite high (90\%; McFadden 1961). In many cases, the highest mortality within the early life history of salmonids occurs during the first few months after emergence (McFadden 1961; Latta 1962; Mortensen 1977b; Elliott 1993a, 1994). Density-dependent effects may account for high mortality of age- 0 salmonids, thereby limiting year-class strength and affecting other regulatory mechanisms later in life (McFadden 1969; Backiel and Le Cren 1978; Titus 1990; Elliott 1994).

Nonnative trout fisheries in White River tailwater reaches downstream of dams in Arkansas and Missouri are intensively angled and managed, similar to tailwater reaches of other southern U.S. regulated rivers (Aggus et al. 1979; Swink 1983; Oliver 1987; Bowman et al. 1996; Weiland and Hayward 1997). Angling pressure in the White River system may exceed 1,000 angler-hours per hectare annually (Bowman et al. 1996), and stock- 

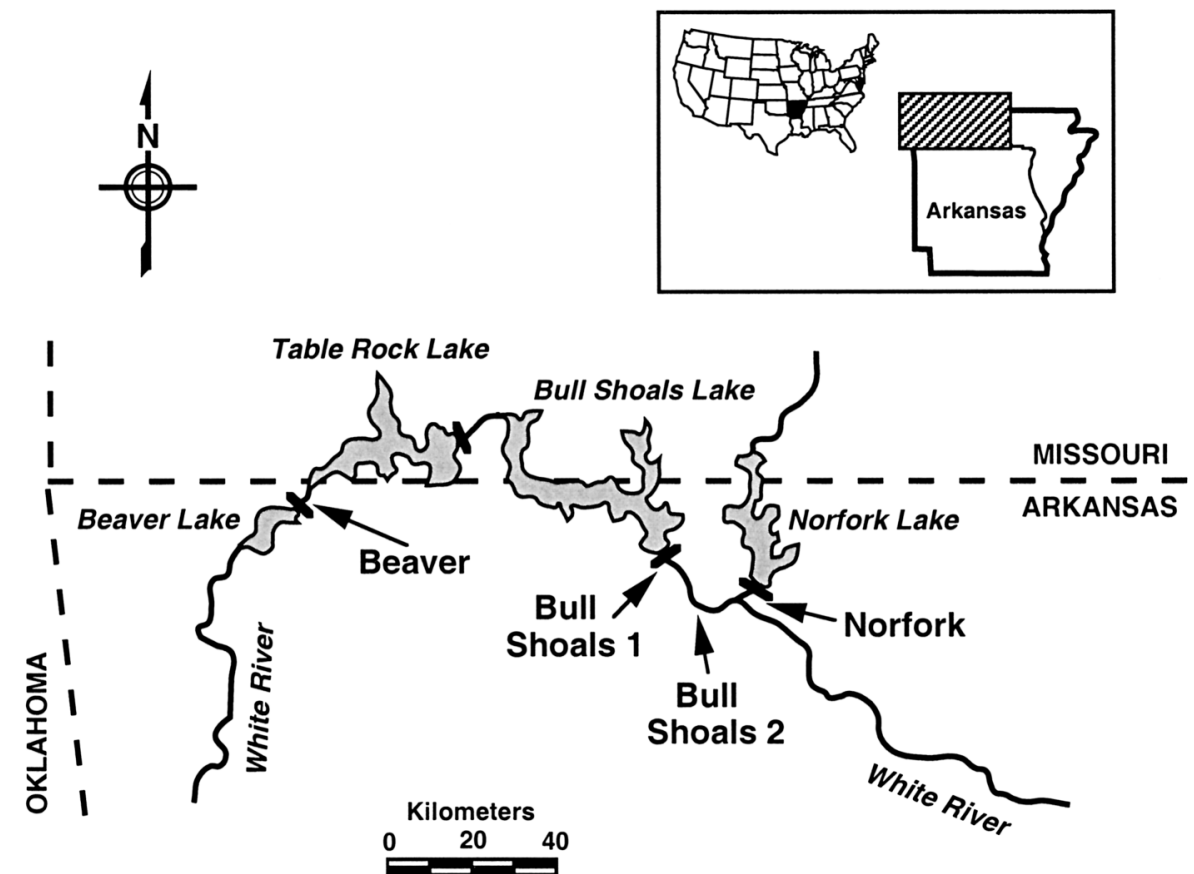

FIgURE 1.-Map of the White River in Arkansas and Missouri, showing the four tailwater study site locations. Thick black lines indicate the dam locations for the reservoirs.

ing densities may reach $24,000 \mathrm{fish} / \mathrm{km}$. State and federal management agencies in Arkansas and Missouri have created a world-class trout fishery in the White River, known for trophy brown trout (Wright 1995). Steps toward improving the sustainability of this fishery include an innovative habitat rehabilitation project on Beaver Tailwater (Filipek 1994; Quinn and Kwak 2000), implementation of creel and size limits in most reaches, and establishment of several areas restricted to catchand-release fishing.

Although trout are not native to the White River system, wild, self-sustaining brown trout populations have been established, with variable reproductive success among tailwater reaches. Beaver Tailwater supports relatively few wild brown trout (J. Stark, Arkansas Game and Fish Commission [AGFC], personal communication), whereas the percentage of wild brown trout in Norfork Tailwater was estimated at 40\% (AGFC, unpublished data), and that in Bull Shoals Tailwater at $67 \%$ (Stark and Bowman 1994). Knowledge of the timing and limiting factors of naturalized trout populations could reduce the need for costly hatchery stocking. Once identified, factors influencing reproductive success could be manipulated to im- prove the natural reproduction and abundance of wild trout.

We monitored spawning and early life stages of brown trout in White River tailwater reaches to determine reproductive chronology and to identify factors contributing to variation in reproductive success. A comparative, investigative approach was adopted to determine the physical or biotic factors responsible for reduced survival in Beaver Tailwater and the observed variation in reproductive success among tailwaters.

\section{Study Area}

The White River originates in northwestern Arkansas, flows northeasterly into Missouri, then southeasterly into Arkansas, where it ultimately joins the Arkansas River (Figure 1). The White River drains $44,400 \mathrm{~km}^{2}$, the largest drainage basin in Arkansas. The river system contains a series of reservoirs created by construction of large hydroelectric dams. We studied three tailwaters: Beaver Tailwater, Bull Shoals Tailwater, and Norfork Tailwater (Figure 1; Pender 1998), hereafter referred to as Beaver, Bull Shoals, and Norfork. Norfork Dam was completed in 1944 (Norfork Tailwater is a tributary of the White River; $4,678 \mathrm{~km}^{2}$ drainage 
area), Bull Shoals Dam in $1952\left(15,633 \mathrm{~km}^{2}\right.$ drainage area), and Beaver Dam in $1965\left(3,072 \mathrm{~km}^{2}\right.$ drainage area) (USACE 1966). Beaver and Norfork dams each create less than 15 river $\mathrm{km}$ with a thermal environment suitable to support trout, and each tailwater was considered one sample site. We sampled two sites within Bull Shoals due to the substantial length of that tailwater. One Bull Shoals study site (Bull Shoals 1) was directly below the dam, and the other (Bull Shoals 2) was 32 river $\mathrm{km}$ downstream of the dam. The approximate study reach lengths were $3.2 \mathrm{~km}$ at Beaver, $2.2 \mathrm{~km}$ at Bull Shoals 1, $1.6 \mathrm{~km}$ at Bull Shoals 2, and 1.0 $\mathrm{km}$ at Norfork.

\section{Methods \\ Field and Laboratory Procedures}

Brown trout fecundity.-To estimate fecundity, a sample of 12 prespawning female brown trout (35-43 cm total length [TL]) was collected from each of the four sampling sites from 25 September to 5 October 1996 with a pulsed-DC, boat-mounted electrofisher. Female trout were measured streamside (nearest $0.1 \mathrm{~cm} \mathrm{TL}$ ) and weighed (nearest 1.0 $\mathrm{g}$ ), and the length and weight were used to calculate a Fulton-type condition factor $\left(K_{\mathrm{TL}}\right)$ (Anderson and Neumann 1996). Scale samples were removed from each fish for age determination (Smith 1954; Jearld 1983). The fish were sacrificed, and their ovaries were removed, weighed, and preserved in a 5\% formalin solution (Klinger and Van Den Avyle 1993).

In the laboratory, total egg number, average egg diameter (nearest $0.01 \mathrm{~mm}$, measured with digital calipers from a random sample of 200 eggs), and total ovary volume (nearest $1.0 \mathrm{~mL}$ ) were determined for each female. Fecundity also was quantified as the gonadosomatic index (GSI $=$ [gonad weight/body weight] $\times 100$ ), which is appropriate for this study because all fish were in the same stage of reproductive development (approximately 2-3 weeks prior to spawning) and were within a very narrow length range (DeVlaming et al. 1982; Erickson et al. 1985). These criteria also justified application of a Fulton-type condition factor.

Spawning and incubation habitat.-To locate and observe spawning trout or the presence of redds, the entire length of each study reach was visually surveyed by walking the shoreline and by boat once per week from 10 October 1996 to 19 January 1997. To relocate and monitor specific redds, we marked them with a metal stake and mapped them by hand and with a global position- ing system (GPS model 96, Rockwell International). We collected redd morphology and microhabitat measurements, including redd length, redd width, distance of the redd from the nearest bank, water depth, mean velocity, water temperature, intragravel temperature (IGT), midcolumn dissolved oxygen concentration, intragravel dissolved oxygen concentration (IGDO), and substrate composition. All initial redd microhabitat measurements were collected at the spawning pit and tailspill separately, except for water temperature, IGT, midcolumn dissolved oxygen concentration, and IGDO. Incubation microhabitat measurements collected from redds following spawning were water depth, mean velocity, water temperature, IGT, midcolumn dissolved oxygen concentration, and IGDO.

Depth was measured with a top-set wading rod (nearest $0.3 \mathrm{~cm}$ ) and velocity was measured with a Marsh-McBirney model 2000 digital flowmeter (nearest $0.01 \mathrm{~m} / \mathrm{s}$ ). Water temperature and dissolved oxygen concentration were measured at each redd with a Yellow Springs Instruments, Inc. (YSI) dissolved oxygen meter. Intragravel dissolved oxygen and IGT were measured by inserting a $60-\mathrm{mL}$ syringe into the substrate and removing a sample of water; the YSI probe was then gently inserted into the syringe to obtain temperature and dissolved oxygen readings. Substrate composition was classified according to a modified Wentworth particle size scale (Bovee and Milhous 1978).

After spawning was complete, and prior to emergence, four redds at each site where spawning was observed (Beaver and Bull Shoals 2) were sampled for substrate with a single-probe, freezecore apparatus (modified from Walkotten 1976). The freeze-core technique was used to preserve vertical stratification of the substrate sample (Everest et al. 1982). The probe was placed in the front half of the tailspill, where eggs are most often found (Ottaway et al. 1981; Chapman 1988; Grost et al. 1991), and was driven to a maximum substrate depth of $25 \mathrm{~cm}$ (Ottaway et al. 1981). The frozen core was then extracted, thawed, and stratified into upper and lower layers to determine if gravel quality varied with depth (Adams and Beschta 1980; Everest et al. 1982; Young et al. 1989). One freeze-core sample was collected per redd, and the remaining redd area was excavated with a shovel to locate any additional eggs.

In the laboratory, each core sample stratum was dried and sorted with six Gilson Company, Inc. USA-standard testing sieves (mesh sizes: 16, 8, 4, 
2,1 , and $0.063 \mathrm{~mm}$ ) placed in geometric progression on a mechanical shaker for $10 \mathrm{~min}$. Each fraction was then weighed separately (nearest $0.01 \mathrm{~g}$ ). From this procedure, percent fines $(<1.0 \mathrm{~mm})$ and the Fredle index (Lotspeich and Everest 1981), which characterizes the suitability of gravel for salmonid incubation and emergence, were determined for each stratum. Both percent fines and the Fredle index were used as spawning gravel descriptors because gravel requirements may change with trout life stage (Chapman 1988; Kondolf 2000).

Age-0 brown trout density and habitat.-As juvenile emergence was expected to occur (Embody 1934), we monitored areas near spawning sites for the presence of age- 0 trout. Once per week from 24 January to 19 November 1997, as much of each reach as possible was surveyed. If we were unable to survey an entire reach on a single occasion, we continued sampling from the previous point on the subsequent visit to complete the survey. Age-0 trout density was approximated by a catch-perunit-effort method, computed as the number of fish captured per kilometer electrofished (fish/km; Malvestuto 1996). Age-0 trout were sampled with a Smith-Root, Inc., Type VII pulsed-DC backpack electrofisher. Trout species were identified according to Bacon (1954), Auer (1982), and Martinez (1984). Age-0 brown trout were measured (nearest $1.0 \mathrm{~mm} \mathrm{TL}$ ) and weighed (nearest $0.01 \mathrm{~g}$ ). Growth rates were compared to density estimates among tailwaters to examine the possibility of densitydependent effects.

Microhabitat characteristics were measured at the capture locations of age- 0 trout. Measurements included water temperature, midcolumn dissolved oxygen concentration, depth, mean velocity, distance from the stream bank, substrate composition, and associated cover. Cover was categorized as boulder $(\geq 250 \mathrm{~mm})$, cobble $(64-249 \mathrm{~mm})$, gravel (8-63 mm), bank vegetation, submersed vegetation, rootwad, or woody debris.

Food availability and diet.-To estimate the density and proportion of food items available to age0 brown trout, benthic and epibenthic invertebrate assemblages were sampled in each tailwater reach during trout juvenile development (12-17 April 1997). Samples were collected from sites varying in physical characteristics at expected and observed locations of age- 0 brown trout. Benthic invertebrates were sampled with a $3.5-\mathrm{cm}$-diameter corer to a substrate depth of $5 \mathrm{~cm}$. Three cores were collected and combined into one sample, and three samples were obtained from each site (nine cores total per site, as per Rabeni et al. [1999]). Epibenthic invertebrates were sampled with a vacuum benthos sampler (Brown et al. 1987). Three epibenthic samples $(100 \mathrm{~L}$ of river water filtered per sample) were collected per site at a depth of $3 \mathrm{~cm}$ above the substrate, the mean focal depth of age-0 trout collected prior to invertebrate sampling. Invertebrate samples were preserved in a solution of 5\% formalin and rose bengal stain. For diet determination, a sample of up to six age- 0 trout per site per day was collected, anesthetized with tricaine methanesulfonate (MS-222) to prevent regurgitation upon preservation, and fixed in $10 \%$ buffered formalin.

In the laboratory, fish and invertebrate samples were rinsed and transferred to $70 \%$ ethanol prior to processing. Stomach contents and invertebrate samples were sorted under a dissecting microscope, counted, and weighed wet (nearest 0.0001 $\mathrm{g}$ ), and a subsample of each taxon was dried and weighed (nearest $0.0001 \mathrm{~g}$ ). Diet was quantified as stomach fullness ([stomach contents wet weight/ fish wet body weight] $\times 100$ ), frequency of occurrence, mean percent composition by number and dry weight, and selectivity relative to food available (Strauss 1979; Bowen 1996). Invertebrates were identified according to Merritt and Cummins (1996) for insects and Thorp and Covich (1991) for other invertebrates.

Predation.-Ozark sculpin Cottus hypselurus (the dominant nonsalmonid fish species) predation on trout eggs and age- 0 brown trout was investigated by collecting sculpin samples of varying sizes (31-99 individuals) by backpack electrofishing once during the brown trout incubation period (230 January 1997) and again during the juvenile development period (18-20 April 1997). Sculpins were anesthetized, preserved, and their stomach contents were extracted, sorted, and analyzed by the same methods used for trout.

Interspecific competition.-The possibility of competition between Ozark sculpins and age-0 brown trout was investigated by examining their diets and densities. Stomach contents of Ozark sculpins (April samples) and age-0 brown trout were compared to determine the degree of diet overlap (Schoener 1971; Bowen 1996). Sculpin population density was estimated by a three-pass removal method with constant sampling effort (maximum-likelihood estimator; Seber 1982; Bohlin et al. 1989; Kwak 1992) from one riffle in each site during 2-30 January 1997. The relationship between sculpin density and trout reproductive success was examined to explore indirect competitive interactions between the species. 
Ancillary data.-Trout stocking information and long-term water quality data were obtained from other sources. Trout stocking information was provided by Greers Ferry National Fish Hatchery, U.S. Fish and Wildlife Service (USFWS), Heber Springs, Arkansas; Joe Hogan State Fish Hatchery, AGFC, Lonoke, Arkansas; and Norfork National Fish Hatchery, USFWS, Mountain Home, Arkansas. Water quality data were obtained from the U.S. Geological Survey (USGS) for Beaver (19671995), Bull Shoals (1967-1996), and Norfork (1948-1996) tailwaters.

\section{Analytical Methods}

All data were analyzed and then examined in aggregate to determine which factors likely contributed to brown trout reproductive failure in Beaver and the variable reproductive success among tailwaters. A significance level $(\alpha)$ of 0.05 was used for all statistical tests. Adult female fecundity, adult female condition, redd gravel quality, water quality variables, age- 0 brown trout stomach fullness, and density and biomass of benthic and epibenthic invertebrates among tailwaters were each analyzed separately by one-way analysis of variance (ANOVA), and when differences were significant, a Tukey multiple comparison test was used to identify the source of the variation (Zar 1996). Because habitat variables were correlated, spawning and age- 0 brown trout microhabitat data (except for age-0 trout cover, which is categorical) were analyzed separately by multivariate ANOVA (MANOVA); when significant differences were detected, stepwise discriminant analysis was then employed to determine which variables best discriminated among sites (SAS Institute 1989). Age0 brown trout length was highly correlated to microhabitat characteristics; therefore, length was treated as a covariate in MANOVA and stepwise discriminant analysis models. Cover associated with age- 0 brown trout occurrences was analyzed with the log-likelihood ratio ( $G$-test; Zar 1996). Based on their frequency distribution, young trout were classified into small $(<65 \mathrm{~mm})$ and large $(\geq 65 \mathrm{~mm})$ length-groups for the analysis of age0 trout cover and for diet comparisons. Ozark sculpins were similarly assigned to small $(<60 \mathrm{~mm})$ and large $(\geq 60 \mathrm{~mm})$ groups for diet comparisons. The analysis of age- 0 brown trout density was performed with a randomized block ANOVA (time [week] was treated as a block), and a Tukey multiple comparison test was used to elucidate differences. Age- 0 trout condition and size were compared with an analysis of covariance (ANCOVA).
Differences in diet overlap between age-0 brown trout and Ozark sculpins were determined by a bootstrap technique (Krebs 1989) to estimate 95\% confidence limits (2.5 and 97.5 quantiles) for all overlap values. For comparison among sites, significant differences in diet were determined by generating a covariance matrix used to compute Hotelling's two-sample $T^{2}$ (Johnson 1998). Sculpin density estimates were compared among sites with separate pairwise Z-tests (Waters and Erman 1990).

Transformations or ranks were employed in cases where data were not normally distributed. The USGS water quality data were compared with a nonparametric procedure (Kruskal-Wallis test; Zar 1996), given that transformation failed to improve normality. Age-0 brown trout density and stomach fullness data were transformed by natural logarithms $\left(\log _{\mathrm{e}}[x+1]\right)$, and condition, length, and weight were $\log _{10}$ transformed (Zar 1996). A power transformation (Draper and Smith 1981) was employed on age-0 trout numerical microhabitat data except for dissolved oxygen concentration and temperature, which were normally distributed.

\section{Results}

\section{Fecundity and Reproductive Chronology}

Significant differences in gonadal measures were found among sites, with brown trout from Beaver showing the lowest values. Gonadosomatic index, egg diameter, gonad volume, and $K_{\mathrm{TL}}$ values were significantly lower at Beaver, but no significant differences were detected among the other three sites (Table 1; $P<0.05$ ). However, for egg number, estimates did not differ between Beaver and Bull Shoals 2. No difference in egg number was found between Bull Shoals 2 and the other sites, whereas Beaver estimates were significantly lower than those for the other sites. Female condition factor calculated with total body weight revealed among-site differences; however, when female body weight minus gonad weight was used to calculate $K_{\mathrm{TL}}$, no significant differences were detected among sites. Scale annuli indicated that female trout collected for this analysis were age 3 $(77 \%$; mean $=3.2 \pm 0.1 \mathrm{SE})$ and age 4 .

Brown trout were first observed spawning on 18 October 1996, and spawning continued through 23 November 1996 at Beaver and Bull Shoals 2. We were unable to observe brown trout spawning at Bull Shoals 1 or Norfork during the 1996 season, due to high water levels. High discharge from 24 November to 8 December 1996 prevented us from 
TABLE 1.-Mean ( $\pm 2 \mathrm{SE}, N=12$ fish per site) egg diameter, egg number, gonad volume, gonadosomatic index (GSI), fish total length, and Fulton-type condition factor $\left(K_{\mathrm{TL}}\right)$ for adult female brown trout at Beaver, Bull Shoals 1 , Bull Shoals 2, and Norfork tailwater sites. Within a row, means with the same letter are not significantly different; ANOVA $=$ analysis of variance.

\begin{tabular}{|c|c|c|c|c|c|}
\hline \multirow[b]{2}{*}{ Measure } & \multicolumn{4}{|c|}{ Site } & \multirow[b]{2}{*}{ ANOVA $P$} \\
\hline & Beaver & Bull Shoals 1 & Bull Shoals 2 & Norfork & \\
\hline Egg diameter (mm) & $\begin{array}{l}3.82 \mathrm{z} \\
(0.24)\end{array}$ & $\begin{array}{l}4.33 \mathrm{y} \\
(0.14)\end{array}$ & $\begin{array}{l}4.33 \mathrm{y} \\
(0.14)\end{array}$ & $\begin{array}{l}4.50 \mathrm{y} \\
(0.11)\end{array}$ & $<0.00001$ \\
\hline Egg number & $\begin{array}{c}1,330 \mathrm{z} \\
(304)\end{array}$ & $\begin{array}{c}2,278 y \\
(280)\end{array}$ & $\begin{array}{c}1,816 \mathrm{zy} \\
(283)\end{array}$ & $\begin{array}{c}1,943 y \\
(296)\end{array}$ & 0.0004 \\
\hline Gonad volume (mL) & $\begin{array}{l}70.00 \mathrm{z} \\
(24.70)\end{array}$ & $\begin{array}{l}159.00 \mathrm{y} \\
(28.69)\end{array}$ & $\begin{array}{l}133.79 \mathrm{y} \\
(25.82)\end{array}$ & $\begin{array}{l}143.5 \mathrm{y} \\
(33.12)\end{array}$ & 0.0003 \\
\hline GSI & $\begin{array}{l}11.49 \mathrm{z} \\
(2.74)\end{array}$ & $\begin{array}{l}20.01 \mathrm{y} \\
(2.44)\end{array}$ & $\begin{array}{l}18.36 \mathrm{y} \\
(1.94)\end{array}$ & $\begin{array}{l}18.16 \mathrm{y} \\
(2.24)\end{array}$ & 0.00003 \\
\hline Total length $(\mathrm{mm})^{\mathrm{a}}$ & $\begin{array}{l}37.8 \mathrm{z} \\
(1.26)\end{array}$ & $\begin{array}{l}39.9 \mathrm{z} \\
(0.80)\end{array}$ & $\begin{array}{l}38.5 \mathrm{z} \\
(1.49)\end{array}$ & $\begin{array}{r}40.1 \mathrm{z} \\
(1.17)\end{array}$ & 0.03 \\
\hline$K_{\mathrm{TL}}$ & $\begin{array}{l}0.99 \mathrm{z} \\
(0.06)\end{array}$ & $\begin{array}{l}1.16 \mathrm{y} \\
(0.07)\end{array}$ & $\begin{array}{l}1.14 \mathrm{y} \\
(0.06)\end{array}$ & $\begin{array}{l}1.13 \mathrm{y} \\
(0.07)\end{array}$ & 0.002 \\
\hline
\end{tabular}

a Significant ANOVA result $(P<0.05)$; Tukey grouping not significant.

effectively searching for spawning trout at any site. In January 1997, prior to observed emergence, age- 0 brown trout with yolk were collected along with electrofished sculpin samples at Beaver. We began to observe and collect emerged brown trout on 28 February 1997.

\section{Spawning and Incubation Habitat}

Significant between-site differences in brown trout spawning microhabitat and redd morphology variables were detected at Beaver and Bull Shoals $2(P=0.01)$; variables that best discriminated between sites were water depth, redd pit substrate, IGT, and midcolumn dissolved oxygen concentra- tion (Table 2; model $P=0.0001$ ). Substrate composition of freeze cores did not differ between sites, but was significantly different between vertical strata at Beaver (Figure 2). Fredle index values did not differ between sites or between strata. Mean percent fines was not significantly different among sites or between strata at Bull Shoals 2; however, percent fines in the upper stratum at Beaver was significantly lower than that in the lower stratum. We did not collect any fish eggs in freezecore samples from redds. However, shovel excavation of redds revealed that eggs were located in the upper stratum $(0.0-12.5 \mathrm{~cm}$ below the substrate surface).

TABLE 2.-Brown trout mean ( $\pm 2 \mathrm{SE})$ spawning microhabitat and redd morphology variables from Beaver $(N=8)$ and Bull Shoals $2(N=15)$ tailwater sites. Data include measurements at redd pit and tailspill. The $F$ - and $P$-values are presented for variables that best discriminated between sites, as determined by stepwise discriminant analysis. Wilks' lambda equals $0.0498(P=0.0001)$.

\begin{tabular}{|c|c|c|c|c|}
\hline \multirow[b]{2}{*}{ Variable } & \multicolumn{2}{|c|}{ Site } & \multirow[b]{2}{*}{$F$} & \multirow[b]{2}{*}{$P$} \\
\hline & Beaver & Bull Shoals 2 & & \\
\hline Distance from bank (m) & $7.6 \quad(2.91)$ & $6.4 \quad(0.86)$ & & \\
\hline Depth $(\mathrm{m})$ & $0.50(0.09)$ & $0.65(0.06)$ & 11.11 & 0.0042 \\
\hline Mean velocity $(\mathrm{m} / \mathrm{s})$ & $0.36(0.06)$ & $0.67(0.09)$ & & \\
\hline Bottom velocity $(\mathrm{m} / \mathrm{s})$ & $0.15(0.03)$ & $0.34(0.05)$ & & \\
\hline Redd pit substrate category mode & Small cobble ${ }^{a}$ & Small cobble ${ }^{a}$ & 6.04 & 0.0267 \\
\hline \multirow[t]{2}{*}{ Redd tailspill ${ }^{\mathrm{b}}$ substrate category mode } & Coarse gravel ${ }^{\mathrm{c}}$ & Coarse gravel ${ }^{\mathrm{c}}$ & & \\
\hline & Very coarse gravel ${ }^{\mathrm{d}}$ & Very coarse gravel ${ }^{\mathrm{d}}$ & & \\
\hline Mid column temperature $\left({ }^{\circ} \mathrm{C}\right)$ & $9.5 \quad(0.92)$ & $13.4 \quad(0.89)$ & & \\
\hline Intragravel temperature $\left({ }^{\circ} \mathrm{C}\right)$ & $9.7 \quad(1.0)$ & $13.5(1.1)$ & 4.69 & 0.0482 \\
\hline Mid column dissolved oxygen (mg/L) & $9.5 \quad(0.62)$ & $10.1 \quad(0.40)$ & 21.69 & 0.0002 \\
\hline Intragravel dissolved oxygen $(\mathrm{mg} / \mathrm{L})$ & $9.3 \quad(0.67)$ & $9.6 \quad(0.36)$ & & \\
\hline Redd length (m) & $2.1 \quad(0.49)$ & $2.0 \quad(0.27)$ & & \\
\hline Redd width (m) & $0.66(0.15)$ & $0.92(0.27)$ & & \\
\hline
\end{tabular}

\footnotetext{
a 64-130 $\mathrm{mm}$ in diameter.

b Bimodal distribution; both listed.

c $16-32 \mathrm{~mm}$ in diameter.

d 32-64 $\mathrm{mm}$ in diameter.
} 

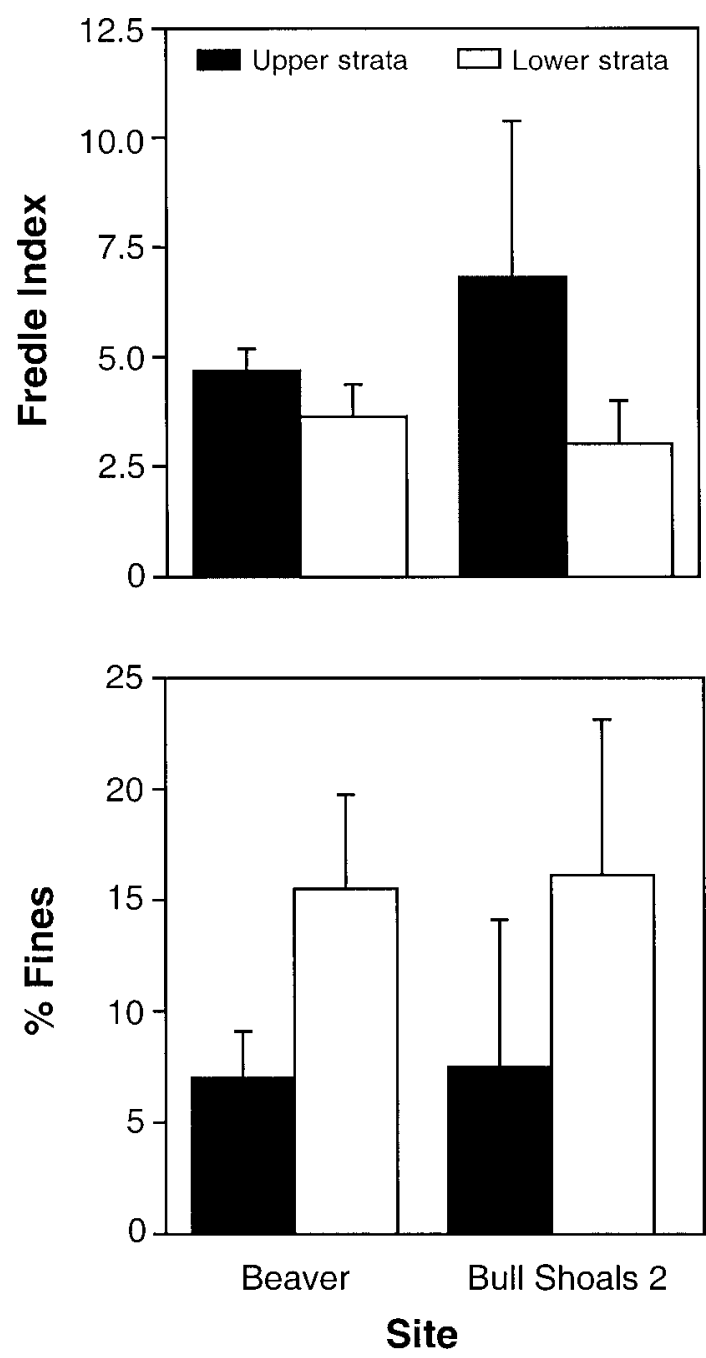

Figure 2.-Brown trout redd gravel quality, quantified as the mean $( \pm \mathrm{SE}, N=4)$ Fredle index (Lotspeich and Everest 1981), and percent fines for Beaver and Bull Shoals 2 tailwaters. No significant differences were detected $(P>0.05)$ between sites or strata for the Fredle index. Significant between-strata differences were detected for percent fines at Beaver $(P=0.03)$. No significant differences were detected for percent fines between strata at Bull Shoals 2 or between sites.

\section{Age-0 Trout Density, Growth, and Habitat}

Significant among-site differences were detected in age- 0 brown trout density and habitat characteristics. Data from Norfork were excluded from this portion of the analysis due to low sample size. Age-0 trout density, expressed as mean weekly catch (fish $/ \mathrm{km}$ ), was significantly higher at Bull Shoals 1 than at Beaver or Bull Shoals 2, but no other significant differences were found between sites (Figure 3). Age-0 brown trout individuals were initially longer at Bull Shoals 2 ( $y$-intercept $P<0.05$ ); no significant difference in growth (measured by length) was found among the three sites included in the analysis (slope $P=0.74$ ). Brown trout weight displayed a similar trend. No significant difference in age-0 brown trout condition was detected among sites $(P=0.45)$. Thus, we found no evidence to suggest the occurrence of density-dependent growth or mortality.

Among-site differences were significant for age0 brown trout continuous microhabitat variables (Table 3; model $P=0.0001$ ) and cover associations (Table 4; $P<0.05)$. Small $(<65 \mathrm{~mm}$ ) age0 brown trout were most frequently associated with woody debris at Beaver, with cobble at Bull Shoals 1 , and with submersed vegetation at Bull Shoals 2 (Table 4). Large ( $\geq 65 \mathrm{~mm}$ ) age-0 brown trout were most frequently associated with bank vegetation at Beaver, with submersed vegetation at Bull Shoals 1, and with woody debris at Bull Shoals 2 .

\section{Food Availability and Diet}

Significant differences in invertebrate food availability occurred among sites. Benthic invertebrate density differed significantly among sites $(P=0.0025)$; density was significantly higher at Norfork than that at Bull Shoals 1, Bull Shoals 2, and Beaver, but no significant difference was detected among the latter three sites (Figure 4). Although ANOVA detected a significant among-site difference in epibenthic invertebrate densities $(P$ $=0.046)$, the Tukey multiple comparison procedure did not elucidate where the difference(s) occurred. No significant difference was detected among sites for benthic and epibenthic invertebrate biomass. In all cases, however, Beaver invertebrate biomass and abundance values were among the two lowest estimates. Because invertebrate abundance does not indicate prey availability per fish among reaches with variable fish densities, we calculated and compared the invertebrate-to-fish ratio among sites, as an index of food biomass available to support age- 0 brown trout. Ratios were calculated by summing benthic and epibenthic invertebrate biomass and dividing that total by the estimated Ozark sculpin biomass, total stocked trout biomass, and age- 0 brown trout biomass individually; these ratios were nearly all lowest at Beaver, suggesting lower food availability there (Table 5).

Age-0 brown trout feeding intensity, measured as stomach fullness, was generally similar among sites. Norfork data were excluded from the diet 


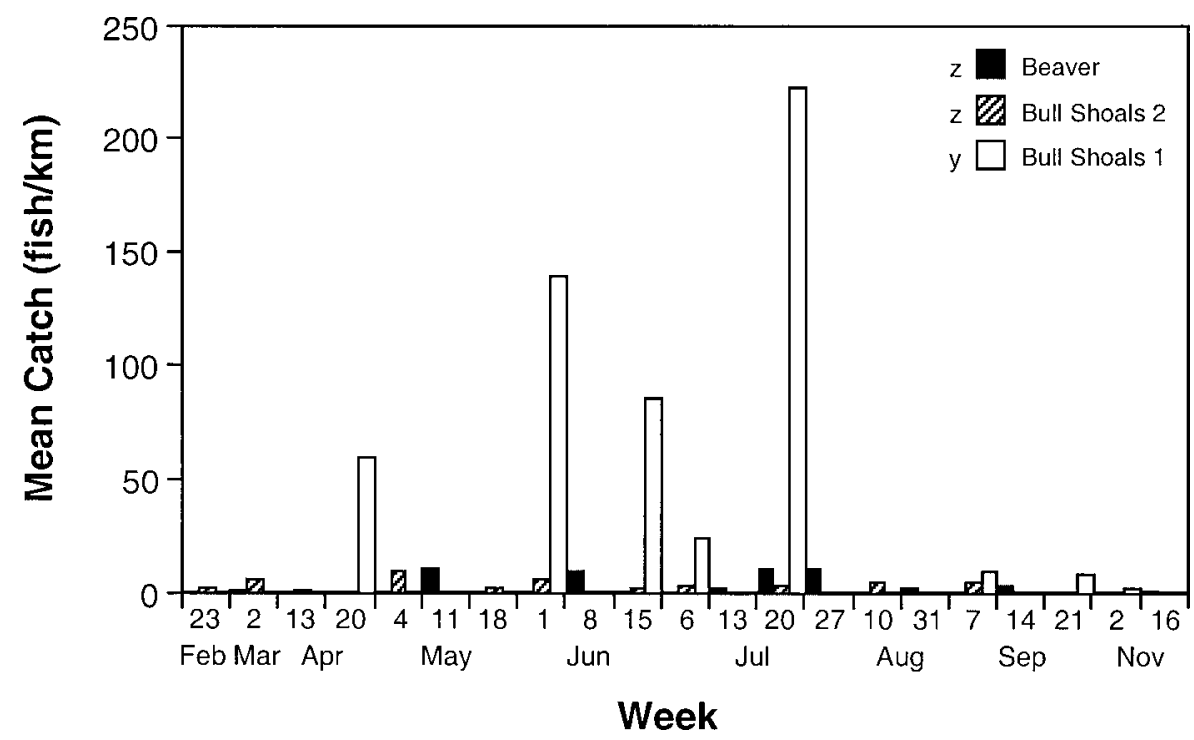

FIGURE 3.-Mean weekly catch of age-0 brown trout for Beaver, Bull Shoals 2, and Bull Shoals 1 tailwaters. Differences among sites were significant $(P=0.0012)$. The Tukey grouping is indicated with lowercase letters $(\mathrm{y}$, $\mathrm{z})$; sites with the same letter are not significantly different $(P>0.05)$.

analysis due to small sample size. No significant differences in mean stomach fullness were found among sites or between small and large age-0 brown trout at Bull Shoals 1 and Bull Shoals 2 . At Beaver, however, small age-0 brown trout had significantly fuller stomachs than large age-0 brown trout $(P=0.013)$.

Small age-0 brown trout at all sites, and large individuals at Beaver, exhibited the most strongly positive selection for Diptera of various life stages, especially Chironomidae larvae (Figure 5). In addition, large age- 0 brown trout positively selected Isopoda and Amphipoda at Bull Shoals 1 and Isopoda, Amphipoda, and Gastropoda at Bull Shoals 2 . When examining all sites, age-0 brown trout expressed the most strongly negative selection for Rotifera, Oligochaeta, and Hydroida; however, these three items may have been digested at a faster rate, causing their importance to be underestimated.

\section{Predation and Competition}

Examination of stomach contents of a combined total of 418 Ozark sculpins collected from two time periods (January and April) at all four sites revealed that no trout eggs or age-0 trout were consumed. Quantitative diet analysis for Ozark sculpins collected in April found many of the same organisms as consumed by age-0 brown trout (Figure 6). Notable features of the diet of Ozark scul-

TABLE 3.-Age-0 brown trout mean $( \pm 2 \mathrm{SE})$ microhabitat variables from Beaver $(N=24)$, Bull Shoals $1(N=96)$, and Bull Shoals $2(N=34)$ tailwater sites. The $F$ - and $P$-values are presented for variables that best discriminated among sites, as determined by stepwise discriminant analysis. Wilks' lambda equals $0.2952(P=0.0001)$.

\begin{tabular}{|c|c|c|c|c|c|}
\hline \multirow[b]{2}{*}{ Variable } & \multicolumn{3}{|c|}{ Site } & \multirow[b]{2}{*}{$F$} & \multirow[b]{2}{*}{$P$} \\
\hline & Beaver & Bull Shoals 1 & Bull Shoals 2 & & \\
\hline Distance from bank (m) & $2.0 \quad(0.83)$ & $2.58(0.37)$ & $0.96(0.34)$ & 7.11 & 0.0012 \\
\hline Distance from cover $(\mathrm{m})$ & $0.13 \quad(0.13)$ & $0.04(0.02)$ & $0.21(0.11)$ & 3.18 & 0.0449 \\
\hline Depth $(\mathrm{m})$ & $0.32 \quad(0.08)$ & $0.25(0.03)$ & $0.20(0.04)$ & 4.31 & 0.0154 \\
\hline Mean velocity $(\mathrm{m} / \mathrm{s})$ & $0.02 \quad(0.01)$ & $0.09(0.02)$ & $0.02(0.01)$ & & \\
\hline Bottom velocity $(\mathrm{m} / \mathrm{s})$ & $0.001(0.001)$ & $0.04(0.01)$ & $0.01(0.01)$ & & \\
\hline Substrate category mode & Sand ${ }^{a}$ & Small cobble ${ }^{b}$ & Sand $^{\mathrm{a}}$ & 10.39 & 0.0001 \\
\hline Temperature $\left({ }^{\circ} \mathrm{C}\right)$ & $12.1 \quad(0.90)$ & $13.7 \quad(0.45)$ & $15.2 \quad(1.2)$ & 19.51 & 0.0001 \\
\hline Dissolved oxygen $(\mathrm{mg} / \mathrm{L})$ & $(0.69)$ & $8.1 \quad(0.19)$ & $10.4 \quad(0.44)$ & 54.07 & 0.0001 \\
\hline
\end{tabular}

a $0.06-1.0 \mathrm{~mm}$ in diameter.

b $64-130 \mathrm{~mm}$ in diameter. 
TABLE 4.-Percent frequency of occurrence of closest cover available to age-0 brown trout for two size-groups (small [ $<65 \mathrm{~mm}]$ and large $[\geq 65 \mathrm{~mm}])$ at Beaver, Bull Shoals 1, and Bull Shoals 2 tailwater sites. Among-site differences in cover type association were significant $(P<0.05)$ for both size-groups.

\begin{tabular}{|c|c|c|c|c|c|c|}
\hline \multirow[b]{3}{*}{ Cover type } & \multicolumn{6}{|c|}{ Site } \\
\hline & \multicolumn{2}{|c|}{ Beaver } & \multicolumn{2}{|c|}{ Bull Shoals 1} & \multicolumn{2}{|c|}{ Bull Shoals 2} \\
\hline & $\begin{array}{c}\text { Small } \\
(N=13)\end{array}$ & $\begin{array}{c}\text { Large } \\
(N=11)\end{array}$ & $\begin{array}{c}\text { Small } \\
(N=71)\end{array}$ & $\begin{array}{c}\text { Large } \\
(N=25)\end{array}$ & $\begin{array}{c}\text { Small } \\
(N=25)\end{array}$ & $\begin{array}{c}\text { Large } \\
(N=9)\end{array}$ \\
\hline \multicolumn{7}{|l|}{ Rock } \\
\hline Boulder ${ }^{\mathrm{a}}$ & 7.14 & 9.09 & 12.68 & 40.00 & 0.00 & 0.00 \\
\hline Cobble $^{\mathrm{b}}$ & 0.00 & 0.00 & 54.92 & 4.00 & 4.35 & 0.00 \\
\hline Gravel $^{\mathrm{c}}$ & 21.43 & 0.00 & 12.68 & 8.00 & 0.00 & 0.00 \\
\hline \multicolumn{7}{|l|}{ Vegetation } \\
\hline Bank & 7.14 & 45.46 & 0.00 & 0.00 & 21.74 & 0.00 \\
\hline Submersed & 14.29 & 18.18 & 18.31 & 44.00 & 65.21 & 33.33 \\
\hline \multicolumn{7}{|l|}{ Wood } \\
\hline Root wad & 14.29 & 0.00 & 0.00 & 0.00 & 8.70 & 11.11 \\
\hline Woody debris & 35.71 & 27.27 & 1.41 & 4.00 & 0.00 & 55.56 \\
\hline
\end{tabular}

$\mathrm{a} \geq 250 \mathrm{~mm}$ in diameter.

b $64-249 \mathrm{~mm}$ in diameter.

c $8-63 \mathrm{~mm}$ in diameter.

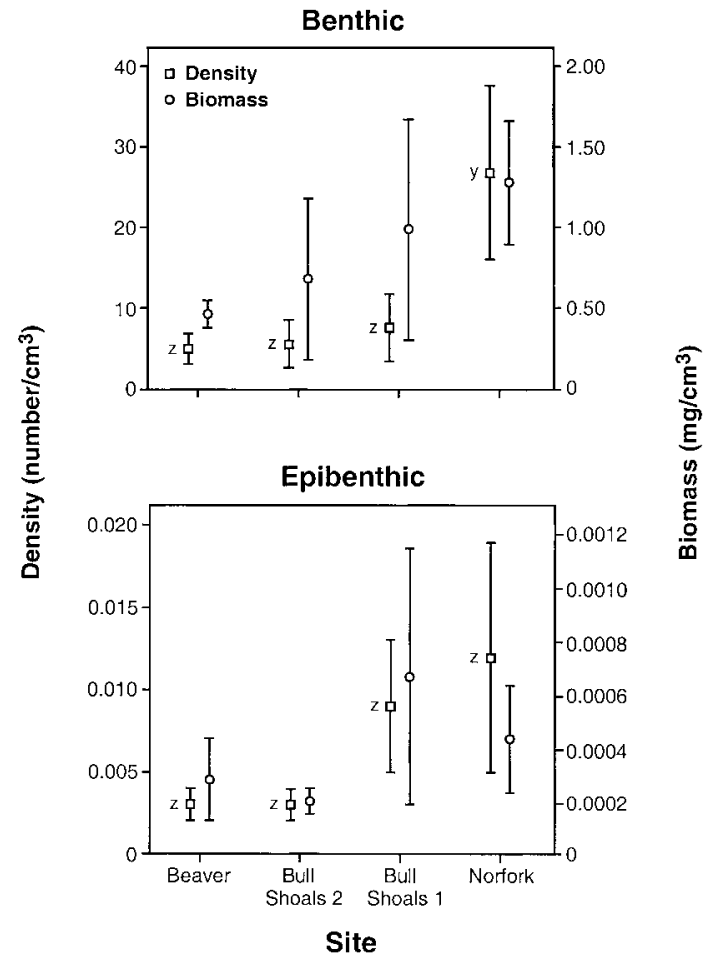

FIGURE 4.-Mean ( $\pm 2 \mathrm{SE}, N=3$ ) density and biomass (wet weight) of benthic and epibenthic invertebrates from Beaver, Bull Shoals 1, Bull Shoals 2, and Norfork tailwaters. Significant among-site differences were detected for benthic $(P=0.0025)$ and epibenthic $(P=$ $0.046)$ densities. The Tukey grouping is indicated with lowercase letters $(\mathrm{y}, \mathrm{z})$; sites with the same letter are not significantly different $(P>0.05)$. No significant difference was detected in biomass among sites. pins as compared with that of age- 0 brown trout were the consumption of plant matter, the inclusion of Trichoptera, and the greater proportion of biomass made up of Oligochaeta (Pender 1998). Although Oligochaeta was an important biomass component, the proportion in the Ozark sculpin diet was lower than in the environment, resulting in negative selectivity (Figure 6). Again, a faster rate of digestion of the soft-bodied oligochaetes could have caused the difference in proportions. Also notable was the presence of sculpin remains in several Ozark sculpin stomachs.

To more quantitatively compare Ozark sculpin (April samples) and age-0 brown trout diets, we calculated Schoener's diet overlap index (Schoener 1971; Table 6). The diet overlap index between Ozark sculpins and age- 0 brown trout differed significantly among sites $(P<0.0001)$ and was highest at Beaver, followed by Bull Shoals 1 . Diet overlap was lowest at Bull Shoals 2. The finding of the highest significant diet overlap index at Beaver indicates that Ozark sculpins and age- 0 brown trout are sharing the same food resources most extensively there, possibly suggestive of competition between the two species.

We estimated Ozark sculpin densities to further investigate possible competitive interactions. Population estimates at Beaver and Bull Shoals 2 differed significantly ( $Z$-test, $P=0.014)$, and differences for all other pairwise comparisons were also significant ( $Z$-test, $P<0.001$; Figure 7). Sculpin densities were highest at Beaver, followed by Bull Shoals 2, Norfork, and Bull Shoals 1. Bull Shoals 1 supported the highest densities of age- 0 brown 
TABLE 5.-Estimates of the total (benthic and epibenthic) mean invertebrate biomass, Ozark sculpin biomass, age-0 brown trout biomass, total biomass of stocked trout (brook trout Salvelinus fontinalis, brown trout, cutthroat trout Oncorhynchus clarki, and rainbow trout O. mykiss) for 1996 and 1997, and ratios of invertebrate biomass to fish biomass at Beaver, Bull Shoals 1, Bull Shoals 2, and Norfork tailwater sites.

\begin{tabular}{|c|c|c|c|c|}
\hline \multirow[b]{2}{*}{ Variable } & \multicolumn{4}{|c|}{ Site } \\
\hline & Beaver & Bull Shoals 1 & Bull Shoals 2 & Norfork \\
\hline \multicolumn{5}{|l|}{ Biomass } \\
\hline Invertebrate $\left(\mu \mathrm{g} / \mathrm{cm}^{3}\right)$ & 459 & 986 & 678 & 1,280 \\
\hline Ozark sculpin $(\mathrm{kg} / \mathrm{ha})$ & 86.2 & 1.0 & 89.1 & 68.1 \\
\hline Age-0 brown trout $(\mathrm{g} / \mathrm{km})$ & 6.8 & 74.4 & 7.6 & \\
\hline \multicolumn{5}{|l|}{ Stocked trout $(\mathrm{kg} / \mathrm{km})$} \\
\hline 1996 & 1,857 & 3,494 & 783 & 2,606 \\
\hline 1997 & 2,693 & 4,240 & 1,036 & 3,065 \\
\hline \multicolumn{5}{|l|}{ Ratio } \\
\hline Invertebrate: Ozark sculpin & 5.3 & $1,017.2$ & 7.6 & 18.8 \\
\hline Invertebrate: age- 0 brown trout & 67.4 & 13.3 & 89.4 & \\
\hline \multicolumn{5}{|l|}{ Invertebrate: stocked trout } \\
\hline 1996 & 0.25 & 0.28 & 0.87 & 0.49 \\
\hline 1997 & 0.17 & 0.23 & 0.65 & 0.42 \\
\hline
\end{tabular}

trout coincident with the lowest densities of Ozark sculpins (Figure 7), providing additional correlative evidence of a competitive interaction between the two species.

\section{Water Quality}

Significant among-site differences were detected in long-term water quality data for 9 of 16 variables examined (Table 7). Significant differences were not detected by the Kruskal-Wallis test for dissolved oxygen concentration, temperature, nitrate concentration, or concentrations of copper, mercury, nickel, and zinc. However, significant differences were detected for alkalinity, conductivity, total phosphate concentration, and concentrations of aluminum, arsenic, cadmium, iron, lead, and manganese. Data from Beaver were the significantly lowest values for alkalinity and conductivity, which may be considered indices of water fertility (Kwak and Waters 1997; Clarke and Scruton 1999), followed by Bull Shoals 1 and Norfork in increasing magnitude. Norfork also was significantly highest in total phosphate concentration, while concentrations at Beaver and Bull Shoals 1 did not differ significantly. The highest concentrations of aluminum and lead occurred at Beaver,

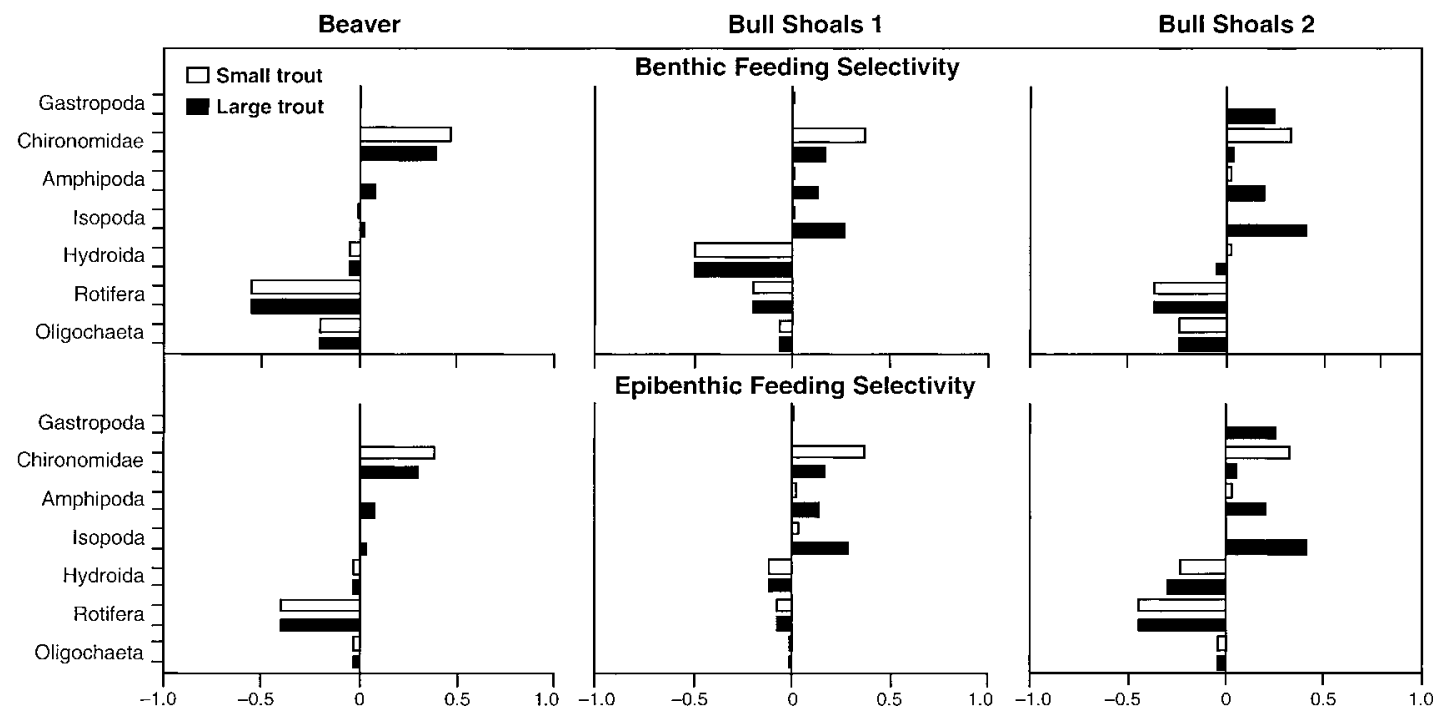

FIGURE 5.-Age-0 brown trout benthic and epibenthic feeding selectivity (Strauss 1979; data include the four taxa with the highest selectivity and the three taxa with the lowest selectivity) for small $(<65 \mathrm{~mm})$ and large $(\geq 65$ $\mathrm{mm}$ ) trout collected at Beaver, Bull Shoals 1, and Bull Shoals 2 tailwaters. See Table 6 for sample sizes. 


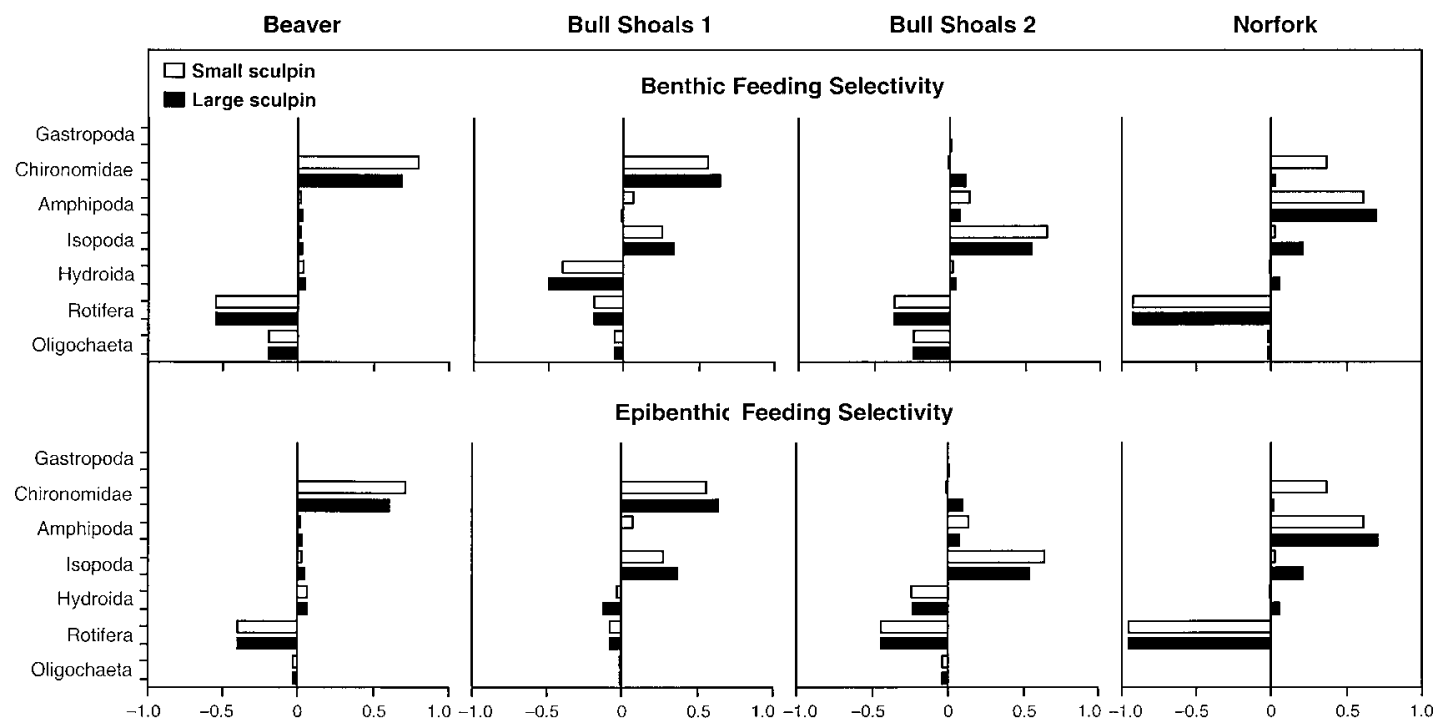

FIGURE 6.-Ozark sculpin benthic and epibenthic feeding selectivity (Strauss 1979; data include the four taxa with the highest selectivity and the three taxa with the lowest selectivity) for small $(<60 \mathrm{~mm})$ and large $(\geq 60 \mathrm{~mm})$ Ozark sculpins collected during April at Beaver, Bull Shoals 1, Bull Shoals 2, and Norfork tailwaters. See Table 6 for sample sizes.

those of arsenic and cadmium at Bull Shoals 1, and those of iron and manganese at Norfork.

\section{Discussion}

\section{Reproductive Chronology and Habitat}

Brown trout in Ozark tailwater rivers spawned during time periods similar to those reported in

TABLE 6.-Schoener's diet overlap index (Schoener 1971; 95\% confidence intervals in parentheses, determined by 2.5 and 97.5 quantiles) for Ozark sculpin of two sizegroups (small $[<60 \mathrm{~mm}]$ and large $[\geq 60 \mathrm{~mm}]$ ) and age- 0 brown trout of two size-groups (small $[<65 \mathrm{~mm}$ ] and large [ $\geq 65 \mathrm{~mm}]$ ) collected at Beaver, Bull Shoals 1, and Bull Shoals 2 tailwater sites. Hotelling's two-sample $T^{2}$ revealed significant differences $(P<0.0001)$ for all pairwise comparisons of analogous indices between sites.

\begin{tabular}{ccc}
\hline \multirow{2}{*}{$\begin{array}{c}\text { Brown trout } \\
\text { size-group }\end{array}$} & \multicolumn{2}{c}{ Ozark sculpin size-group } \\
\cline { 2 - 3 } & Small & Large \\
\hline & Beaver \\
Small $(N=11)$ & $0.77(0.72-0.81)$ & $0.76(0.72-0.80)$ \\
Large $(N=12)$ & $0.73(0.68-0.77)$ & $0.73(0.68-0.76)$ \\
& Bull Shoals 1 & \\
& $N=23$ & $N=9$ \\
Small $(N=33)$ & $0.38(0.34-0.42)$ & $0.37(0.33-0.41)$ \\
Large $(N=15)$ & $0.44(0.35-0.52)$ & $0.42(0.36-0.49)$ \\
& Bull Shoals 2 & \\
& $N=17$ & $N=14$ \\
Small $(N=23)$ & $0.07(0.02-0.10)$ & $0.06(0.02-0.10)$ \\
Large $(N=9)$ & $0.54(0.42-0.65)$ & $0.44(0.32-0.56)$ \\
\hline
\end{tabular}

the literature for other riverine populations (McFadden et al. 1965; Anderson 1983; Nelson 1986; Grost et al. 1991). Although brown trout in our study may have spawned later than the last observed date (23 November), we were unable to observe later spawning activity due to continuous high water levels. Beginning on 13 December, the tailwaters were again accessible, but brown trout were not observed spawning after that date.

Rapidly fluctuating flow conditions are a critical factor with which spawning trout below peaking hydroelectric dams must contend, and flow appeared to affect White River brown trout spawning timing and microhabitat. Trout were observed to abandon redd construction in response to increasing water releases for hydropower generation. When flow stabilized, trout again initiated spawning. It was difficult to observe trout spawning in midchannel habitats during high flows due to water surface turbulence. However, we observed brown trout spawning near the river margins during high flows, as was reported by Lister and Walker (1966). When the water level receded in the White River, dry redds were present (12 observed). Redd dewatering has been recorded previously in the literature for other stream-dwelling trout populations (Bauersfeld 1978; Anderson and Nehring 1985) and may be mitigated by the establishment of minimum flows.

Although the flow regime in White River tail- 


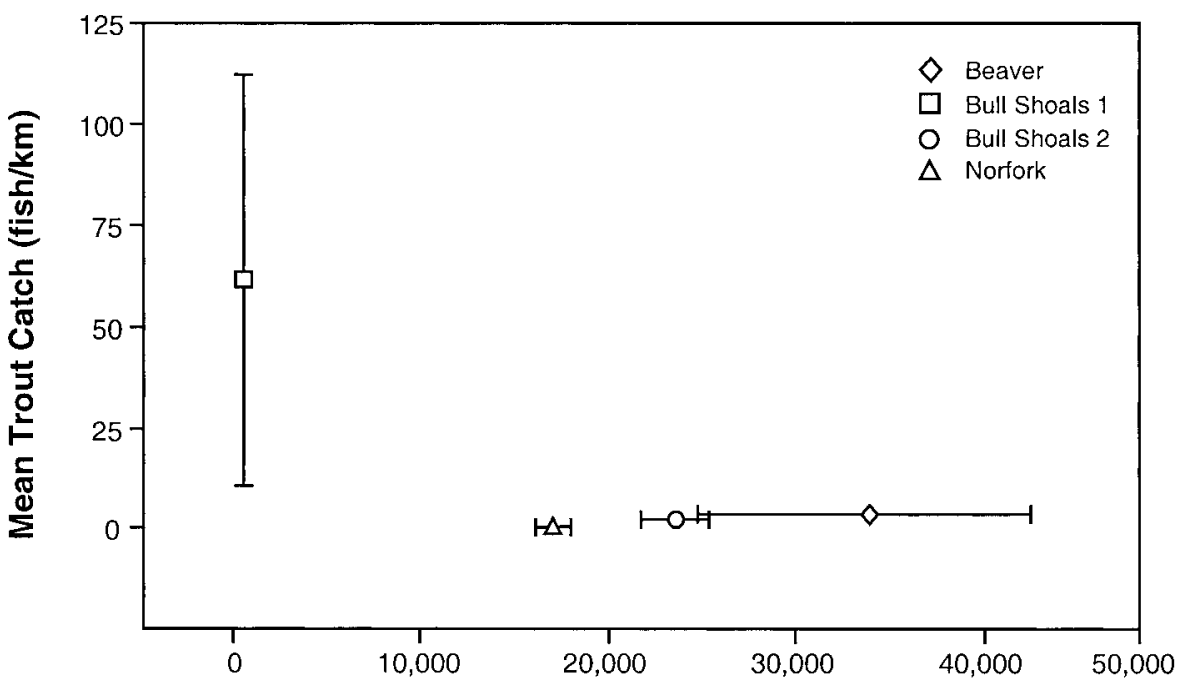

\section{Sculpin Density (fish/ha)}

Figure 7.-Mean ( \pm 2 SE) weekly catch of age-0 brown trout versus mean ( \pm 2 SE) Ozark sculpin density for Beaver, Bull Shoals 1, Bull Shoals 2, and Norfork tailwaters. Significant differences were detected among sites $(P$ $<0.05)$ for both mean brown trout catch and mean Ozark sculpin density. The standard errors for brown trout catch are too small to appear at this scale for Beaver, Bull Shoals 2, and Norfork.

waters may negatively affect brown trout survival, it is unlikely that other spawning microhabitat characteristics contribute to lower survival because the values we measured for depth, mean velocity, substrate size, temperature, and dissolved oxygen concentration fell within or near generalized suitable or optimum values reported in the literature for the species (Raleigh et al. 1986; Stickney 1991). However, it is possible that dissolved oxygen fell below optimum concentrations during part of the incubation period. We measured dissolved oxygen concentration at redds only during daylight hours, and although the means of dissolved oxygen concentrations collected continuously by the USGS were above minimum desirable levels for trout, some of the recorded concentrations were much lower (minima: $5.1 \mathrm{mg} / \mathrm{L}$ at Beaver, $3.1 \mathrm{mg} / \mathrm{L}$ at Bull Shoals 1 , and $2.4 \mathrm{mg} / \mathrm{L}$ at Norfork). It is also unlikely that redd gravel quality contributed to lower reproductive success at Beaver and Bull Shoals 2. White River Fredle index values were relatively high (Lotspeich and Everest 1981) and percent fines were low compared to data reported for other brown trout spawning areas (Chapman 1988; Bjornn and Reiser 1991; Maret et al. 1993), indicating suitable substrate availability.

Emergence of young brown trout in the White River system began on 23 February, which is among the earliest emergence times reported in the literature for brown trout in North American streams (Beyerle and Cooper 1960; Avery 1980; Nelson 1986). Age-0 brown trout in Ozark tailwaters occupied habitats near stream margins, a finding previously reported by other researchers (Moore and Gregory 1988; Bozek and Rahel 1991; Harris et al. 1992; La Voie and Hubert 1996). At the onset of dam water releases, we observed age0 trout descending into crevices between gravel particles as velocity increased. This anecdotal evidence indicates that the trout were able to use gravel interstices as refugia from high velocities. Age-0 brown trout also were associated with bank vegetation, boulder, cobble, submersed vegetation, rootwad, and woody debris, with some variability among sites. In addition to cover type, significant among-site differences were found for dissolved oxygen concentration, temperature, substrate particle size, bank distance, depth, and cover distance of age- 0 brown trout microhabitats. However, as with spawning microhabitat, the data for age-0 brown trout microhabitats fell within or near generalized suitable or optimum values reported in the literature for the species (Raleigh et al. 1986; Stickney 1991). These findings suggest that suitable spawning and age-0 trout habitats were available at each site, and although the total amount of suitable habitat may have been important, logistic 
TABLE 7.-Mean ( \pm 2 SE) values of water quality variables for Beaver (1967-1995), Bull Shoals 1 (1967-1996), and Norfork (1948-1996) tailwater sites. (U.S. Geological Survey, unpublished data). No data were available for the cadmium concentration at Norfork. Tukey grouping is indicated with lowercase letters $(\mathrm{x}, \mathrm{y}, \mathrm{z})$. Within rows, means with the same letter are not significantly different.

\begin{tabular}{|c|c|c|c|c|}
\hline \multirow{2}{*}{$\begin{array}{c}\text { Water quality } \\
\text { variable }\end{array}$} & \multicolumn{3}{|c|}{ Site } & \multirow{2}{*}{$\begin{array}{l}\text { Kruskal- } \\
\text { Wallis } P\end{array}$} \\
\hline & Beaver & Bull Shoals 1 & Norfork & \\
\hline Alkalinity $\left(\mathrm{mg} / \mathrm{L}\right.$ as $\left.\mathrm{CaCO}_{3}\right)$ & $\begin{array}{c}63.13 \mathrm{z} \\
(0.49, N=55)\end{array}$ & $\begin{array}{c}125.15 \mathrm{y} \\
(2.34, N=40)\end{array}$ & $\begin{array}{c}167.79 \mathrm{x} \\
(4.45, N=24)\end{array}$ & 0.0001 \\
\hline Aluminum $(\mu \mathrm{g} / \mathrm{L})$ & $\begin{array}{c}86.73 \mathrm{z} \\
(25.33, N=55)\end{array}$ & $\begin{array}{c}40.41 \mathrm{y} \\
(7.90, N=32)\end{array}$ & $\begin{array}{c}80.00 \mathrm{z} \\
(32.41, N=36)\end{array}$ & 0.006 \\
\hline Arsenic $(\mu \mathrm{g} / \mathrm{L})$ & $\begin{array}{c}1.34 \mathrm{z} \\
(0.42, N=58)\end{array}$ & $\begin{array}{c}2.46 \mathrm{y} \\
(0.86, N=52)\end{array}$ & $\begin{array}{c}1.21 \mathrm{z} \\
(0.30, N=34)\end{array}$ & 0.0006 \\
\hline Cadmium $(\mu \mathrm{g} / \mathrm{L})$ & $\begin{array}{c}1.60 \mathrm{z} \\
(0.80, N=5)\end{array}$ & $\begin{array}{c}12.95 \mathrm{y} \\
(3.62, N=22)\end{array}$ & & 0.024 \\
\hline Conductivity $\left(\mu \mathrm{S} / \mathrm{cm}\right.$ at $\left.25^{\circ} \mathrm{C}\right)$ & $\begin{array}{c}139.00 \mathrm{z} \\
(3.63, N=65)\end{array}$ & $\begin{array}{c}255.90 \mathrm{y} \\
(4.40, N=62)\end{array}$ & $\begin{array}{c}322.90 \mathrm{x} \\
(5.65, N=51)\end{array}$ & 0.0001 \\
\hline Copper $(\mu \mathrm{g} / \mathrm{L})$ & $\begin{array}{c}10.39 \\
(9.66, N=54)\end{array}$ & $\begin{array}{c}8.60 \\
(2.47, N=47)\end{array}$ & $\begin{array}{c}4.08 \\
(1.53, N=27)\end{array}$ & 0.14 \\
\hline Dissolved oxygen $(\mathrm{mg} / \mathrm{L})$ & $\begin{array}{c}9.37 \\
(0.51, N=60)\end{array}$ & $\begin{array}{c}8.46 \\
(0.69, N=61)\end{array}$ & $\begin{array}{c}9.02 \\
(0.84, N=45)\end{array}$ & 0.23 \\
\hline Iron $(\mu \mathrm{g} / \mathrm{L})$ & $\begin{array}{c}116.67 \mathrm{z} \\
(33.52, N=60)\end{array}$ & $\begin{array}{c}88.18 \mathrm{y} \\
(66.59, N=62)\end{array}$ & $\begin{array}{c}135.10 \mathrm{z} \\
(44.36, N=53)\end{array}$ & 0.0001 \\
\hline Lead $(\mu \mathrm{g} / \mathrm{L})$ & $\begin{array}{c}7.24 \mathrm{zy} \\
(7.21, N=55)\end{array}$ & $\begin{array}{c}6.39 \mathrm{z} \\
(2.03, N=51)\end{array}$ & $\begin{array}{c}3.28 \mathrm{y} \\
(1.87, N=27)\end{array}$ & 0.029 \\
\hline Manganese ( $\mu \mathrm{g} / \mathrm{L})$ & $\begin{array}{c}70.60 \mathrm{z} \\
(30.29, N=65)\end{array}$ & $\begin{array}{c}32.49 \mathrm{y} \\
(8.49, N=68)\end{array}$ & $\begin{array}{c}144.75 \mathrm{x} \\
(42.46, N=59)\end{array}$ & 0.0001 \\
\hline Mercury $(\mu \mathrm{g} / \mathrm{L})$ & $\begin{array}{c}0.13 \\
(0.03, N=57)\end{array}$ & $\begin{array}{c}0.22 \\
(0.09, N=34)\end{array}$ & $\begin{array}{c}2.63 \\
(4.58, N=34)\end{array}$ & 0.18 \\
\hline Nickel $(\mu g / L)$ & $\begin{array}{c}9.16 \\
(10.40, N=56)\end{array}$ & $\begin{array}{c}2.04 \\
(0.88, N=26)\end{array}$ & $\begin{array}{c}2.62 \\
(0.82, N=27)\end{array}$ & 0.03 \\
\hline Nitrate $(\mathrm{mg} / \mathrm{L}$ as $\mathrm{N})$ & $\begin{array}{c}0.33 \\
(0.05, N=58)\end{array}$ & $\begin{array}{c}0.35 \\
(0.06, N=63)\end{array}$ & $\begin{array}{c}0.26 \\
(0.04, N=39)\end{array}$ & 0.11 \\
\hline Temperature $\left({ }^{\circ} \mathrm{C}\right)$ & $\begin{array}{c}9.98 \\
(0.97, N=60)\end{array}$ & $\begin{array}{c}10.20 \\
(0.71, N=61)\end{array}$ & $\begin{array}{c}10.39 \\
(0.68, N=46)\end{array}$ & 0.14 \\
\hline Total phosphate $\left(\mathrm{mg} / \mathrm{L}\right.$ as $\left.\mathrm{PO}_{4}\right)$ & $\begin{array}{c}0.04 \mathrm{z} \\
(0.01, N=27)\end{array}$ & $\begin{array}{c}0.03 \mathrm{z} \\
(0.01, N=20)\end{array}$ & $\begin{array}{c}0.08 \mathrm{y} \\
(0.04, N=30)\end{array}$ & 0.0009 \\
\hline Zinc $(\mu \mathrm{g} / \mathrm{L})$ & $\begin{array}{c}26.84 \\
(21.60, N=56)\end{array}$ & $\begin{array}{c}16.25 \\
(4.12, N=55)\end{array}$ & $\begin{array}{c}34.88 \\
(25.55, N=27)\end{array}$ & 0.99 \\
\hline
\end{tabular}

constraints precluded collection of habitat availability data.

\section{Trophic Conditions}

Adult female brown trout at Beaver had lower body condition and fewer and smaller eggs than females at other sites, corresponding to the lower reproductive success at Beaver. Furthermore, average fecundity was lower and average egg diameter was smaller for females at Beaver than literature values for brown trout of the same size range (Taube 1976). Likewise, GSI values were significantly lowest at Beaver and fell below reported values for the same size range of brown trout (Avery 1985).

Juvenile trout survival has been positively related to egg size (Bagenal 1969a; Hutchings 1991; Ojanguren et al. 1996; Einum and Fleming 2000), and this relation may persist for up to $50 \mathrm{~d}$ of exogenous feeding (Hutchings 1991). Smaller egg size and lower fecundity indicate that the brown trout population at Beaver is at an early reproductive disadvantage relative to populations at the other sites. Lower female fecundity likely contributed to the lower density of age-0 brown trout at Beaver relative to Bull Shoals 1. Similarly low densities were estimated at Bull Shoals 2, but these differences cannot be attributed to lower gonadal measures as is possible for Beaver. The very low age-0 trout densities at Norfork may be due to high water releases from Norfork Dam during the entire spawning period.

Variation in trout fecundity has been attributed to differences in genetic stock (Bromage et al. 1990), food quantity (Scott 1962; McFadden et al. 1965; Bagenal 1969b; Jonsson and Jonsson 1999), stream fertility (McFadden et al. 1965), and concentrations of various metals in stream water (Lam 1983; Moore and Ramamoorthy 1984). All brown trout in the White River system originate from the same genetic stock (T. Penniston, AGFC, personal communication); however, we detected differences 
in metal concentrations, invertebrate abundance, and alkalinity among sites. Of the metals with significantly different among-site concentrations (aluminum, arsenic, cadmium, iron, lead, and manganese), only cadmium and lead have been reported to affect fish reproduction (Lam 1983; Moore and Ramamoorthy 1984). The concentrations of lead at Beaver, Bull Shoals, and Norfork were well below the limits required to influence salmonid health, but cadmium concentrations at Beaver and Bull Shoals were above the listed optimum (Wedemeyer 1977). It seems unlikely that cadmium concentration alone would negatively affect female fecundity at Beaver but not at Bull Shoals; however, cadmium could act in combination or synergistically with other stressors occurring at Beaver. Metals in streams also may negatively affect invertebrates (Moore and Ramamoorthy 1984). Although not examined here, metal concentrations may contribute to the varied invertebrate abundances we found.

The invertebrate food base available to age- 0 and adult brown trout at Beaver was less abundant than that of the other sites sampled. An insufficient food base would make it more difficult for trout to meet their routine energy requirements, possibly contributing to reduced fecundity and condition of adult brown trout females. Invertebrate abundance and composition vary seasonally (Rabeni 1996); therefore stream invertebrate surveys may warrant multiple samplings through the year to achieve an adequate estimate of abundance. However, relative to less modified systems, tailwaters below peaking hydroelectric dams generally support reduced invertebrate taxa, increased numbers of certain invertebrate species, and lower overall invertebrate abundance (Walburg et al. 1981; Gislason 1985) and may prevent the establishment of normal, variable benthic invertebrate communities (Fisher and LaVoy 1972). In White River tailwaters, we found the same trends in invertebrate density among sites as reported by Blanz et al. (1970) 30 years ago. Blanz et al. (1970) found the highest density and biomass of invertebrates at Norfork, followed by Bull Shoals 1, Bull Shoals 2, and Beaver. The dominant taxa among reaches were also similar to those reported by Blanz et al. (1970). Therefore, we remain confident that our sampling provides an adequate basis for our conclusions on the trends that we observed.

Growth, condition, and stomach fullness were not significantly different for age-0 brown trout among sites. Elliott (1993a) similarly found high growth rates among surviving age-0 trout, but de- termined that starvation caused high mortality among young trout. Self-thinning of age-0 trout populations may have occurred early, at the start of exogenous feeding, resulting in fish densities corresponding to the carrying capacity of the studied tailwaters of the White River system (Elliott 1993b; Armstrong 1997).

Water fertility, indexed as alkalinity and conductivity, was significantly lowest at Beaver. Conductivity and alkalinity are related to the production of both invertebrates (Cada et al. 1987; Stickney and Kohler 1990) and fish (Kwak and Waters 1997; Clarke and Scruton 1999). McFadden et al. (1965) found that in streams of relatively low alkalinity, trout produced fewer and smaller eggs, indicative of lower productivity. Desirable alkalinity for trout culture has been reported as 80 $200 \mathrm{mg} / \mathrm{L}$ (Stickney 1991), with 120-400 mg/L considered optimum for fish growth (Piper et al. 1982). The average alkalinity at Beaver was lower $\left(63 \mathrm{mg} / \mathrm{L}\right.$ as $\left.\mathrm{CaCO}_{3}\right)$ than the minimum desirable level and ranks among the lowest concentrations reported for trout streams in North America (Kwak and Waters 1997).

Not only were available invertebrate densities lowest at Beaver, but the highest significant diet overlap between sculpins and age-0 brown trout also was found there. Furthermore, the density of sculpins was significantly highest at Beaver, contributing to an inverse trend between sculpin and trout density among sites. Our results yield correlative evidence of competition between these two fish species. However, a shortcoming of this component of our research is that invertebrates were only identified to order or family for most taxa, which is one of the criticisms presented by Moyle (1977) of studies that examine competition between these fish groups. Moyle's other two primary criticisms were that invertebrate abundances were not determined in previous studies and that there are differences in feeding modes between these two species. We estimated invertebrate densities, and the pattern among sites suggests a more limited food resource at Beaver, where diet overlap was highest between sculpins and age-0 brown trout. Moreover, age- 0 trout are more dependent on bottom fauna than are older juveniles and adults (Bachman 1984; Grant and Noakes 1987), so that there is a greater likelihood of food competition with sculpins (Koster 1937). Furthermore, Moyle (1977) suggested that competition between these fish groups may occur under conditions of overexploitation or environmental disturbance, which may be the case at Beaver. As a final point, these 
results are an indication that competition is occurring and suggest that a more rigorous examination of competition between Ozark sculpins and brown trout may be worthwhile.

We did not observe predation by sculpins on age- 0 brown trout or brown trout eggs. However, others have documented sculpin predation on trout (Phillips and Claire 1966; Gaudin and Caillere 2000) and trout behavioral modification in the presence of sculpins (Bardonnet and Heland 1994; Roussel and Bardonnet 1999; Gaudin and Caillere 2000). Typically, sculpin predation on trout has been documented under artificial conditions, such as those associated with traps and aquaria; in stream environments, the presence of eggs or age0 trout in the sculpin diet occurs on an infrequent basis (Moyle 1977).

Density-dependent growth was not detected in this study, although density-dependent growth (Mortensen 1977b; Backiel and Le Cren 1978; Grant and Kramer 1990; Titus 1990) and mortality (Chapman 1966; Mortensen 1977a, 1977b; Backiel and Le Cren 1978; Elliott 1984, 1994) have often been documented for salmonids. The apparent absence of density-dependent growth in our study may be due to the difficulty of detecting it via observational data (Jenkins et al. 1999). Also, age0 brown trout in the White River system may not be present in densities high enough to cause density-dependent mortality (Knapp et al. 1998).

In summary, differences in trophic conditions among sites were detected that likely contributed to the lower reproductive success of brown trout at Beaver. The proximate causes of reproductive failure at Beaver were the lower condition of adult female trout, fewer and smaller eggs, lower age0 trout densities, lower food base availability, and possible competition with sculpins via higher sculpin densities and greater diet overlap. However, the ultimate cause of poor reproductive success at Beaver may be lower water fertility and lower productive capacity for the present trout densities. Other possible proximate factors that were ruled out as substantial contributors to varied reproductive success were brown trout spawning microhabitat, age- 0 trout microhabitat, and predation on trout eggs or juveniles by sculpins. However, the amount of microhabitat area available was not evaluated. The quantities of spawning habitat and complex microhabitat available to age- 0 trout are important in other systems (Knapp et al. 1998; Vehanen et al. 2000) and may have contributed to the observed variation among Ozark tailwaters. Though logistic constraints prevented us from ex- ploring this factor, microhabitat availability may warrant future study in the White River system. The concentrations of heavy metals present were not determined to be a substantial influence, but it is possible that in combination with the other stressors occurring at Beaver they negatively affect the trout there.

\section{Management Implications}

The lower water fertility at Beaver implies a reduction of the natural system productive capacity. Although it is difficult to alter water fertility, managers may be able to manipulate instream habitat features, thereby increasing habitat complexity to enhance productivity. However, the response to habitat improvement efforts has varied among salmonid populations and species; see Hunt (1988), Reeves et al. (1991), and Thorn et al. (1997) for reviews. For example, stream habitat improvement efforts in one of the large Ozark tailwaters that we studied (Beaver) failed to increase numbers of large brown trout but did increase abundances of rainbow trout and small trout of all species (Quinn and Kwak 2000). Similarly, instream habitat improvement efforts increased overall trout abundance in small, free-flowing Minnesota streams but did not increase large brown trout abundance (Thorn et al. 1997). The results of habitat manipulations in Colorado and Washington trout streams also varied according to fish size and species (Gowan and Fausch 1996; Cederholm et al. 1997). Habitat manipulation can increase salmonid spawning (House and Boehne 1985) and the number of age-0 salmonids (House and Boehne 1985; Moore and Gregory 1988). It appears that the type of habitat modification that will be most beneficial to trout may need to be assessed separately for each river (Hunt 1988; Reeves et al. 1991) and will depend on the specific management goals (Thorn et al. 1997; Quinn and Kwak 2000).

Another approach to improving production efficiency and natural reproduction among White River tailwater reaches is to evaluate and refine the multispecies trout stocking regime to adjust for variability in productive capacity among tailwaters. As was found in the Lake Taneycomo Tailwater (Weiland and Hayward 1997), another White River tailwater in Missouri, conditions at Beaver may lead to invertebrate densities that are inadequate to support trout growth and reproduction. Weiland and Hayward (1997) concluded that high trout stocking rates led to a reduced prey base, and they suggested that stocking reduction or adjustments based on expected angler pressure could 
achieve improvements in rainbow trout growth. Similarly, adjustments in the annual frequency and timing of stocking, in combination with flow and habitat management, may facilitate enhancement of wild brown trout populations in White River tailwaters of Arkansas. Furthermore, such strategies should be considered for use in other regulated rivers where there is an interest in improving natural reproduction, abundance, and quality of wild trout.

\section{Acknowledgments}

We thank the many students, faculty, and staff from the Department of Biological Sciences, University of Arkansas, that assisted with field and laboratory data collection, especially Casey Pevey. We appreciate the assistance of Lynette Duncan and Jim Dunn for statistical consultation and Claudia Bailey and Arthur Brown for helpful discussions that enhanced this research. John Stark and Stan Todd of the Arkansas Game and Fish Commission facilitated site selection and provided insightful background information. Jim Gaston of Gaston's White River Resort, Jim Griffin of Bull Shoals State Park, and Donny Wallace of Brainerd's Bend Resort provided housing, camping, and boat access. Information on water releases was provided by John Kielczewski of the U.S. Army Corps of Engineers and David Kennedy of Southwestern Power Administration. Trout stocking information was provided by Sherri Shoults of Greers Ferry National Fish Hatchery, Kay Hester of Joe Hogan State Fish Hatchery, and Monroe Schmidt of Norfork National Fish Hatchery. This research was funded by the U.S. Fish and Wildlife Service and the Arkansas Cooperative Fish and Wildlife Research Unit.

\section{References}

Adams, J. N., and R. L. Beschta. 1980. Gravel bed composition in Oregon coastal streams. Canadian Journal of Fisheries and Aquatic Sciences 37:15141521.

Aggus, L. R., D. I. Morais, and R. F. Baker. 1979. Evaluation of the trout fishery in the tailwater of Bull Shoals Reservoir, Arkansas, 1971-73. Proceedings of the Annual Conference Southeastern Association of Fish and Wildlife Agencies 31(1977):565-573.

Anderson, D. W. 1983. Factors affecting brown trout reproduction in southeastern Minnesota streams. Minnesota Department of Natural Resources Section of Fisheries Investigational Report 376.

Anderson, R. M., and R. B. Nehring. 1985. Impacts of stream discharge on trout rearing habitat and trout recruitment in the South Platte River, Colorado. Pages 59-64 in F. W. Olsen, R. G. White, and R.
H. Hamre, editors. Symposium on small hydropower and fisheries. American Fisheries Society, Western Division, Bethesda, Maryland.

Anderson, R. O., and R. M. Neumann. 1996. Length, weight, and associated structural indices. Pages 447-482 in Murphy and Willis (1996).

Armstrong, J. D. 1997. Self-thinning in juvenile sea trout and other salmonid fishes revisited. Journal of Animal Ecology 66:519-526.

Auer, N. A., editor. 1982. Identification of larval fishes of the Great Lakes basin with emphasis on the Lake Michigan drainage. Great Lakes Fishery Commission, Special Publication 82-3, Ann Arbor, Michigan.

Avery, E. L. 1980. Factors influencing reproduction of brown trout above and below a flood water detention dam on Trout Creek, Wisconsin. Wisconsin Department of Natural Resources, Research Report 106, Madison.

Avery, E. L. 1985. Sexual maturity and fecundity of brown trout in central and northern Wisconsin streams. Wisconsin Department of Natural Resources Technical Bulletin 154.

Bachman, R. A. 1984. Foraging behavior of free-ranging wild and hatchery brown trout in a stream. Transactions of the American Fisheries Society 113: $1-32$.

Backiel, T., and E. D. Le Cren. 1978. Some density relationships for fish populations parameters. Pages 279-302 in S.D. Gerking, editor. Ecology of freshwater fish production. Blackwell Scientific Publications, Oxford, UK.

Bacon, E. H. 1954. Field characters of prolarvae and alevins of brook, brown and rainbow trout in Michigan. Copeia 1954:232.

Bagenal, T. B. 1969a. Relationship between egg size and fry survival in brown trout Salmo trutta L. Journal of Fish Biology 1:349-353.

Bagenal, T. B. 1969b. The relationship between food supply and fecundity in brown trout Salmo trutta L. Journal of Fish Biology 1:167-182.

Bardonnet, A., and M. Heland. 1994. The influence of potential predators on the habitat preferenda of emerging brown trout. Journal of Fish Biology 45: $131-142$.

Bauersfeld, K. 1978. The effect of daily flow fluctuations on spawning fall chinook in the Columbia River. Washington Department of Fisheries Technical Report 38.

Beyerle, G. B., and E. L. Cooper. 1960. Growth of brown trout in selected Pennsylvania streams. Transactions of the American Fisheries Society 89: 255-262.

Bjornn, T. C., and D. W. Reiser. 1991. Habitat requirements of salmonids in streams. Pages 83-138 in W. R. Meehan, editor. Influences of forest and rangeland management on salmonid fishes and their habitats. American Fisheries Society, Special Publication 19, Bethesda, Maryland.

Blanz, R. E., C. E. Hoffman, R. J. Kilambi, and C. R. Liston. 1970. Benthic macroinvertebrates in cold tailwaters and natural streams in the state of Ar- 
kansas. Proceedings of the Annual Conference Southeastern Association of Game and Fish Commissioners 23(1969):281-292.

Bohlin, T., S. Hamrin, T. G. Heggberget, G. Rasmussen, and S. J. Saltveit. 1989. Electrofishing-theory and practice with special emphasis on salmonids. Hydrobiologia 173:9-43.

Bovee, K. D., and R. Milhous. 1978. Hydraulic simulation in instream flow studies: theory and technique. U.S. Fish and Wildlife Service FWS/OBS$78 / 33$.

Bowen, S. H. 1996. Quantitative description of the diet. Pages 513-532 in Murphy and Willis (1996).

Bowman, D. W., T. R. Bly, S. P. Filipek, C. A. Perrin, J. D. Stark, and B. K. Wagner. 1996. Angler use, success, and characteristics on Greers Ferry Tailwater, Arkansas, with implications to management. Proceedings of the Annual Conference Southeastern Association of Fish and Wildlife Agencies 48(1994):499-511.

Bozek, M. A., and F. J. Rahel. 1991. Assessing habitat requirements of young Colorado River cutthroat trout by use of macrohabitat and microhabitat analyses. Transactions of the American Fisheries Society 120:571-581.

Bromage, N., P. Hardiman, J. Jones, J. Springate, and V. Bye. 1990. Fecundity, egg size and total egg volume differences in 12 stocks of rainbow trout, Oncorhynchus mykiss Richardson. Aquaculture and Fisheries Management 21:269-284.

Brown, A. V., M. D. Schram, and P. P. Brussock. 1987. A vacuum benthos sampler suitable for diverse habitats. Hydrobiologia 153:241-247.

Cada, G. F., J. M. Loar, and M. J. Sale. 1987. Evidence of food limitation of rainbow and brown trout in southern Appalachian soft-water streams. Transactions of the American Fisheries Society 116:692-702.

Cederholm, C. J., R. E. Bilby, P. A. Bisson, T. W. Bumstead, B. R. Fransen, W. J. Scarlett, and J. W Ward. 1997. Response of juvenile coho salmon and steelhead to placement of large woody debris in a coastal Washington stream. North American Journal of Fisheries Management 17:947-963.

Chapman, D. W. 1966. Food and space as regulators of salmonid populations in streams. American Naturalist 100:345-357.

Chapman, D. W. 1988. Critical review of variables used to define effects of fines in redds of large salmonids. Transactions of the American Fisheries Society 117: $1-21$.

Clarke, K. D., and D. A. Scruton. 1999. Brook trout production dynamics in the streams of a low fertility Newfoundland watershed. Transactions of the American Fisheries Society 128:1122-1229.

DeVlaming, V., G. Grossman, and F. Chapman. 1982. On the use of the gonosomatic index. Comparative Biochemical Physiology 73A:31-39.

Draper, N. R., and H. Smith. 1981. Applied regression analysis. Wiley, New York.

Einum S., and I. A. Fleming. 2000. Selection against late emergence and small offspring in Atlantic salmon (Salmo salar). Evolution 54:628-639.
Elliott, J. M. 1984. Numerical changes and population regulation in young migratory trout Salmo trutta in a Lake District stream, 1966-83. Journal of Animal Ecology 53:327-350.

Elliott, J. M. 1993a. The pattern of natural mortality throughout the life cycle in contrasting populations of brown trout, Salmo trutta L. Fisheries Research 17:123-136.

Elliott, J. M. 1993b. The self-thinning rule applied to juvenile sea trout, Salmo trutta. Journal of Animal Ecology 62:371-379.

Elliott, J. M. 1994. Quantitative ecology and the brown trout. Oxford University Press, New York.

Embody, G. C. 1934. Relation of temperature to the incubation periods of eggs of four species of trout. Transactions of the American Fisheries Society 64: 281-292.

Erickson, D. L., J. E. Hightower, and G. D. Grossman. 1985. The relative gonadal index: an alternative index for quantification of reproductive condition. Comparative Biochemical Physiology 81A:117120.

Everest, F. H., F. B. Lotspeich, and W. R. Meehan. 1982. New perspectives on sampling, analysis, and interpretation of spawning gravel quality. Pages 325333 in N. B. Armantrout, editor. Acquisition and utilization of aquatic habitat inventory information. American Fisheries Society, Western Division, Bethesda, Maryland.

Filipek, S. P. 1994. Beaver Tailwater restoration and habitat improvement project. Arkansas Game and Fish Commission, Administrative Report, Little Rock.

Fisher, S. G., and A. LaVoy. 1972. Differences in littoral fauna due to fluctuating water levels below a hydroelectric dam. Journal of the Fisheries Research Board of Canada 29:1472-1476.

Gaudin, P., and L. Caillere. 2000. Experimental study of the influence of presence and predation by sculpin, Cottus gobio L., on the drift of emergent brown trout, Salmo trutta L. Archiv fuer Hydrobiologie 147:257-271.

Gislason, J. C. 1985. Aquatic insect abundance in a regulated stream under fluctuating and stable diel flow patterns. North American Journal of Fisheries Management 5:39-46.

Gowan, C., and K. D. Fausch. 1996. Long-term demographic responses of trout populations to habitat manipulation in six Colorado streams. Ecological Applications 6:931-946.

Grant, J. W. A., and D. L. Kramer. 1990. Territory size as a predictor of the upper limit to population density of juvenile salmonids in streams. Canadian Journal of Fisheries and Aquatic Sciences 47:17241737.

Grant, J. W. A., and D. L. G. Noakes. 1987. Movers and stayers: foraging tactics of young-of-the-year brook charr, Salvelinus fontinalis. Journal of Animal Ecology 56:1001-1013.

Grost, R. T., W. A. Hubert, and T. A. Wesche. 1991. Description of brown trout redds in a mountain 
stream. Transactions of the American Fisheries Society 120:582-588.

Harris, D. D., W. A. Hubert, and T. A. Wesche. 1992. Habitat use by young-of-year brown trout and effects on weighted usable area. Rivers 3:99-105.

House, R. A., and P. L. Boehne. 1985. Evaluation of instream enhancement structures for salmonid spawning and rearing in a coastal Oregon stream. North American Journal of Fisheries Management 5:283-295.

Hunt, R. L. 1988. A compendium of 45 trout stream habitat development evaluations in Wisconsin during 1953-1985. Wisconsin Department of Natural Resources Technical Bulletin 162.

Hutchings, J. A. 1991. Fitness consequences of variation in egg size and food abundance in brook trout Salvelinus fontinalis. Evolution 45:1162-1168.

Jearld, A., Jr. 1983. Age determination. Pages 301-324 in L. A. Nielsen and D. L. Johnson, editors. Fisheries techniques. American Fisheries Society, Bethesda, Maryland.

Jenkins, T. M., Jr., S. Diehl, K. W. Kratz, and S. D. Cooper. 1999. Effects of population density on individual growth of brown trout in streams. Ecology 80:941-956.

Johnson, D. E. 1998. Applied multivariate methods for data analysts. Duxbury Press, Pacific Grove, California.

Jonsson, N., and B. Jonsson. 1999. Trade-off between egg mass and egg number in brown trout. Journal of Fish Biology 55:767-783.

Klinger R. C., and M. J. Van Den Avyle. 1993. Preservation of striped bass eggs: effects of formalin concentration, buffering, stain, and initial stage of development. Copeia 1993:1114-1119.

Knapp, R. A., V. T. Vredenburg, and K. R. Matthews. 1998. Effects of stream channel morphology on golden trout spawning habitat and recruitment. Ecological Applications 8:1104-1117.

Kondolf, G. M. 2000. Assessing salmonid spawning gravel quality. Transactions of the American Fisheries Society 129:262-281.

Koster, W. J. 1937. The food of sculpins (Cottidae) in central New York. Transactions of the American Fisheries Society 66:374-382.

Krebs, C. J. 1989. Ecological methodology. Harper Collins Publishers, New York.

Kwak, T. J. 1992. Modular microcomputer software to estimate fish population parameters, production rates and associated variance. Ecology of Freshwater Fish 1:73-75.

Kwak, T. J., and T. F. Waters. 1997. Trout production dynamics and water quality in Minnesota streams. Transactions of the American Fisheries Society 126: 35-48.

Lam, T. J. 1983. Environmental influences on gonadal activity in fish. Pages 65-116 in W. S. Hoar, D. J. Randall, and E. M. Donaldson, editors. Fish physiology, volume 9, part B. Academic Press, New York.

Latta, W. C. 1962. Periodicity of mortality of brook trout during first summer of life. Transactions of the American Fisheries Society 91:408-411.

La Voie, W. J., IV, and W. A. Hubert. 1996. Use of three types of stream-margin habitat by age-0 brown trout late in the growing season. Hydrobiologia 317:8995.

Lister, D. B., and C. E. Walker. 1966. The effect of flow control on freshwater survival of chum, coho, and chinook salmon in the Big Qualicum River. Canadian Fish Culturist 37:3-25.

Lotspeich, F. B., and F. H. Everest. 1981. A new method for reporting and interpreting textural composition of spawning gravel. U.S. Forest Service Research Note PNW-369.

Malvestuto, S. P. 1996. Sampling the recreational creel. Pages 591-620 in Murphy and Willis (1996).

Maret, T. R., T. A. Burton, G. W. Harvey, and W. H. Clark. 1993. Field testing of new monitoring protocols to assess brown trout spawning habitat in an Idaho stream. North American Journal of Fisheries Management 13:567-580.

Martinez, A. M. 1984. Identification of brook, brown, rainbow, and cutthroat trout larvae. Transactions of the American Fisheries Society 113:252-259.

McFadden, J. T. 1961. A population study of the brook trout, Salvelinus fontinalis. Wildlife Monographs 7: $1-73$.

McFadden, J. T. 1969. Dynamics and regulation of salmonid populations in streams. Pages 313-329 in T. G. Northcote, editor. Symposium on salmon and trout in streams. University of British Columbia, H. R. Macmillan Lectures in Fisheries, Vancouver.

McFadden, J. T., E. L. Cooper, and J. K. Andersen. 1965. Some effects of environment on egg production in brown trout (Salmo trutta). Limnology and Oceanography 10:88-95.

McNeil, W. J., and W. H. Ahnell. 1964. Success of pink salmon spawning relative to size of spawning bed materials. U.S. Fish and Wildlife Service Special Scientific Report-Fisheries 469.

Merritt, R. W., and K. W. Cummins, editors. 1996. An introduction to the aquatic insects of North America, 3rd edition. Kendall-Hunt, Dubuque, Iowa.

Mills, D. 1971. Salmon and trout: a resource, its ecology, conservation and management. St. Martin's Press, New York.

Moore, J. W., and S. Ramamoorthy. 1984. Heavy metals in natural waters: applied monitoring and impact assessment. Springer-Verlag, New York.

Moore, K. M. S., and S. V. Gregory. 1988. Response of young-of-the-year cutthroat trout to manipulation of habitat structure in a small stream. Transactions of the American Fisheries Society 117:162-170.

Mortensen, E. 1977a. Density-dependent mortality of trout fry (Salmo trutta L.) and its relationship to the management of small streams. Journal of Fish Biology 11:613-617.

Mortensen, E. 1977b. Population, survival, growth and production of trout Salmo trutta in a small Danish stream. Oikos 28:9-15.

Moyle, P. B. 1977. In defense of sculpins. Fisheries 2(1): 20-23. 
Murphy, B. R., and D. W. Willis, editors. 1996. Fisheries techniques, 2nd edition. American Fisheries Society, Bethesda, Maryland.

Nelson, F. A. 1986. Effect of flow fluctuations on brown trout in the Beaverhead River, Montana. North American Journal of Fisheries Management 6:551559.

Ojanguren, A. F., F. G. Reyes-Gavilan, and F. Brana. 1996. Effects of egg size on offspring development and fitness in brown trout, Salmo trutta L. Aquaculture 147:9-20.

Oliver, M. L. 1987. The rainbow trout fishery in the Bull Shoals-Norfork tailwaters, Arkansas, 197181. Proceedings of the Annual Conference Southeastern Association of Fish and Wildlife Agencies 38(1984):549-561.

Ottaway, E. M., P. A. Carling, A. Clarke, and N. A. Reader. 1981. Observations on the structure of brown trout, Salmo trutta Linnaeus, redds. Journal of Fish Biology 19:593-607.

Pender, D. R. 1998. Factors influencing brown trout reproductive success in Ozark tailwater rivers. Master's thesis. University of Arkansas, Fayetteville.

Phillips, R. W., and E. W. Claire. 1966. Intragravel movement of reticulate sculpin, Cottus perplexus and its potential as a predator on salmonid embryos. Transactions of the American Fisheries Society 95: 210-212.

Piper, R. G., I. B. McElwain, L. E. Orme, J. P. McCraren, L. G. Fowler, and J. R. Leonard. 1982. Fish hatchery management. U.S. Fish and Wildlife Service, Washington, D.C.

Quinn, J. W., and T. J. Kwak. 2000. Use of rehabilitated habitat by brown trout and rainbow trout in an Ozark tailwater river. North American Journal of Fisheries Management 20:737-751.

Rabeni, C. F. 1996. Invertebrates. Pages 335-352 in Murphy and Willis (1996).

Rabeni, C. F., N. Wang, and R. J. Sarver. 1999. Evaluating adequacy of the representative stream reach used in invertebrate monitoring programs. Journal of the North American Benthological Society 18: 284-291.

Raleigh, R. F., L. D. Zuckerman, and P. C. Nelson. 1986. Habitat suitability index models and instream flow suitability curves: brown trout. U.S. Fish and Wildlife Service Biological Report 82-10-124.

Reeves, G. H., J. D. Hall, T. D. Roelofs, T. L. Hickman, and C. O. Baker. 1991. Rehabilitating and modifying stream habitats. Pages 519-557 in W. R. Meehan, editor. Influences of forest and rangeland management on salmonid fishes and their habitats. American Fisheries Society, Special Publication 19, Bethesda, Maryland.

Roussel, J.-M., and A. Bardonnet. 1999. Ontogeny of diel pattern of stream-margin habitat use by emerging brown trout, Salmo trutta, in experimental channels: influence of food and predator presence. Environmental Biology of Fishes 56:253-262.

SAS Institute. 1989. SAS/STAT user's guide, version 6,4 th edition, volume 2 . SAS Institute, Cary, North Carolina.
Schoener, T. W. 1971. Theory of feeding strategies. Annual Review of Ecology and Systematics 2:369-404.

Scott, D. P. 1962. Effect of food quantity on fecundity of rainbow trout, Salmo gairdneri. Journal of the Fisheries Research Board of Canada 19:715-731.

Seber, G. A. F. 1982. The estimation of animal abundance and related parameters, 2 nd edition. Charles Griffin, London.

Smith, S. H. 1954. Method of producing plastic impressions of fish scales without using heat. Progressive Fish-Culturist 16:75-78.

Stark, J., and D. Bowman. 1994. 1993 annual trout population report: Bull Shoals Tailwater. Arkansas Game and Fish Commission, Administrative Report, Little Rock.

Stickney, R. R., editor. 1991. Culture of salmonid fishes. CRC Press, Boca Raton, Florida.

Stickney, R. R., and C. C. Kohler. 1990. Maintaining fishes for research and teaching. Pages 633-663 in C. B. Schreck and P. B. Moyle, editors. Methods for fish biology. American Fisheries Society, Bethesda, Maryland.

Strauss, R. E. 1979. Reliability estimates for Ivlev's electivity index, the forage ratio, and a proposed linear index of food selection. Transactions of the American Fisheries Society 108:344-352.

Swink, W. D. 1983. Survey of stocking policies for tailwater trout fisheries in the southern United States. Progressive Fish-Culturist 45:67-71.

Taube, C. M. 1976. Sexual maturity and fecundity in brown trout of the Platte River, Michigan. Transactions of the American Fisheries Society 105:529533.

Thorn, W. C., C. S. Anderson, W. E. Lorenzen, D. L. Hendrickson, and J. W. Wagner. 1997. A review of trout management in southeast Minnesota streams. North American Journal of Fisheries Management 17:860-872.

Thorp, J. H., and A. P. Covich, editors. 1991. Ecology and classification of North American freshwater invertebrates. Academic Press, New York.

Titus, R. G. 1990. Territorial behavior and its role in population regulation of young brown trout (Salmo trutta): new perspectives. Annales Zoologici Fennici 27:119-130.

USACE (U.S. Army Corps of Engineers). 1966. Reservoir regulation manual for Beaver, Table Rock, Bull Shoals, and Norfork reservoirs. USACE, Little Rock, Arkansas.

Vehanen, T., P. L. Bjerke, J. Heggenes, A. Huusko, and A. Maki-Petays. 2000. Effect of fluctuating flow and temperature on cover type selection and behaviour by juvenile brown trout in artificial flumes. Journal of Fish Biology 56:923-937.

Walburg, C. H., J. F. Novotny, K. E. Jacobs, W. D. Swink, T. M. Campbell, J. M. Nestler, and G. E. Saul. 1981. Effects of reservoir releases on tailwater ecology: a literature review. Office, Chief of Engineers, U.S. Army, Environmental and Water Quality Operational Studies, Technical Report E81-12, Washington, D.C.

Walkotten, W. J. 1976. An improved technique for 
freeze sampling streambed sediments. U.S. Forest Service Research Note PNW-281.

Waters, W. E., and D. C. Erman. 1990. Research methods: concept and design. Pages 1-34 in C. B. Schreck, and P. B. Moyle, editors. Methods for fish biology. American Fisheries Society, Bethesda, Maryland.

Wedemeyer, G. A. 1977. Environmental requirements for fish health. Pages 41-55 in Proceedings from the international symposium on disease of cultured salmonids. Tavolek Inc., Redmond, Washington.

Weiland, M. A., and R. S. Hayward. 1997. Cause for the decline of large rainbow trout in a tailwater fishery: too much putting or too much taking? Transactions of the American Fisheries Society 126: 758-773.

Wright, S. 1995. Ozark trout tales: a fishing guide for the White River system. White River Chronicle, Fayetteville, Arkansas.

Young, M. K., W. A. Hubert, and T. A. Wesche. 1989. Substrate alteration by spawning brook trout in a southeastern Wyoming stream. Transactions of the American Fisheries Society 118:379-385.

Zar, J. H. 1996. Biostatistical analysis, 3rd edition. Prentice-Hall, Upper Saddle River, New Jersey. 